\title{
Rafine Edilmiş Güç: Bir Mücadele Alanı Olarak Erken Cumhuriyet Döneminde Şeker Şirketleri
}

\author{
DOI: 10.26466/opus.744886
}

*

\author{
Özgür Çetiner * \\ * Dr. Öğr. Üyesi, Bilecik Şeyh Edebali Üniversitesi/UBF, Bilecik/Türkiye \\ E-Posta: ozgur.cetiner@bilecik.edu.tr \\ ORCID: $\underline{0000-0001-5830-2587}$ \\ $\ddot{O} z$
}

Cumhuriyetin kuruluşuyla uygulama alanı bulan şeker faaliyetleri, bir taraftan yeni rejimin toplumsal sınıflarla olan iliş̧ki biçimleri, diğer taraftan kapitalizmin dışarıdaki verili koşullarının bir bileşkesi olarak şekillenmiştir. Şirketler biçiminde örgütlenen şeker üretimi, tanınan pek çok ayrıcalık ve muafiyetin ötesinde, devletle iç içe gelişen simbiyotik bir nitelik taşımıştır. Her aşamasına yoğun bir milliyetçi söylemin eşlik ettiği şeker şirketlerinin kuruluş ve işleyiş süreci, ayrımsız bir şekilde iktisadi ve siyasal alanları kat ederek, devletin içsel mimarisinin şekillenmesinde önemli bir işlev görmüş̧ür. Yasal statüleri, kazançları ve bilançolarıyla şirketler, Veblenci anlamda endüstriye değil, iş alanına ait kurumlardır. Dolayısıyla, şirketleri ortak iyiye dönük kalkınmacı bir retorikle ele almak mümkün değildir. Veblen'in kavramlarını kullanan 'güç olarak sermaye' teorisine göre, iş alanının temel algoritması kapitalizasyondur. Bu çalışmada, şeker şirketlerine ilişkin tüm faaliyetlerin, konu hakkında yapılan çalışmaların aksine, kapitalizasyon mekanizmasıyla ve iş alanının gereksinmeleriyle koşullandığı ve bu çerçevede belirlendiği iddia edilmiştir. Sayısal verilerle de desteklenen arşiv kaynaklarının kullanıldığı nitel çalışmada, Türkiye'de erken dönem cumhuriyet tarihinde, şeker şirketleri üzerinden iş alanında özgül bir kapitalizasyon mekanizmasının oluşturulduğu bulgulanmıştır.

Anahtar Kelimeler: Kapitalizasyon, Farklılaşmış birikim, Sabotaj 


\title{
Refined Power: Sugar Companies in the Early Republican Period as the Site of Contest
}

\begin{abstract}
Sugar operations which found scope of practice by the establishment of the republic in Turkey, have been shaped as the forms of new regime with social classes on one hand, and, on the other hand, as a resultant of capitalism's given conditions abroad. Sugar production, organized in the form of companies, had a symbiotic qualification developed interpenetrated with the state, beyond many privileges and exemptions given. An intensive nationalist discourse played along with the foundational and operational process of the sugar companies. This process unexceptionally functioned crucially in the embodiment of the internal architecture of the state by getting over the economic and political spheres. In Veblenian terms, the companies, with their legal statuses, profits and financial accounts are institutions which belong to the business space, not the industry. Hence, it is not possible to approach the companies with a developmentalist rhetoric for a common good. According to the theory of 'capital as power' which uses the concepts of Veblen, the basic algorithm of the business space is capitalization. Contrary to the studies on this issue, this study claims that all activities related to sugar companies are conditioned by the capitalization mechanism and the requirements of the business space and determined within this framework. This qualitative study which used archive resources was also supported by quantitative data and it found out that a specific capitalization mechanism was constituted in the business space through sugar companies in the early history of the republic in Turkey.
\end{abstract}

Keywords: Capitalization, Differential accumulation, Sabotage 


\section{Giriş}

"İşte Türk Şekeri, işte Türk toprağından, Türk sa'y-u amelinden (iş ve iş gücü)

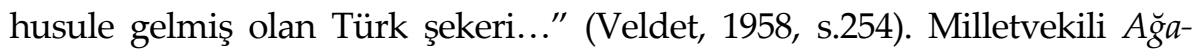
oğlu'nun Alpullu Şeker Fabrikası'nın açılışı dolayısıyla kaleme aldığı yazıdan yapılan bu alıntının benzerlerini dönem boyunca pek çok yerde bulmak mümkündür. Örneğin milletvekili Şeref Aykut Alpullu için benzer ifadeler kullanmıştır. "İşte Alpullu, tarihler yaratmış olan Türk ulusuna çok yaraşan ilk iştir ki, yalnız savaş alanlarında değil bilgi, iş, baysallık (refah) yollarında Türkün ne yüksek bir gidiş ve kavrayış eri olduğunu gösteren Türk Parası ile Türk alın teri ile yücelmiş ilk belge, ilk anıttır." (1935, s.3). Falih Rıfkı da "Cuma günü Uşak'ta ikinci Türk fabrikasının resmi küşadı yapılmıştır. Bu fabrika dahi, diğeri gibi, milli uyanışın eseridir" diyerek, Uşak Şeker Fabrikası'nın açlışını duyurmuştur (Veldet, 1958, s.86). Benzer bir şekilde Mustafa Kemal 1933 yılında kurulan üçüncü fabrika için düşüncelerini "Eskişehir Şeker Fabrikası milli ülküye derin alakanın yükselmiş değerli vesikasıdır" şeklinde ifade etmiştir (Hakimiyeti Milliye, 6 Aralık 1933, s.1). Öte yandan şeker sanayinin 1934 yılında Turhal'da kurulan son fabrikayla tamamlandığını belirten Kütahya Milletvekili Nuri Beyle açılışa katılan Başbakan İnönü yaptığı konuşmada "milli sanayi olmadıkça refaha kavuşulamaz" demiştir (Milliyet, 20 Ekim 1934, s.1) Şeker şirketlerinin kuruluş mukaveleleri de benzer milli unsurlar taşımaktadır. Örneğin şirketlerin sözleşmelerine, yönetim kurulu üyelerinin yarıdan fazlasının Türk olması ya da çalıştırılacak memurların tamamen Türklerden seçilmesi gibi şartlar konduğu gözlenmektedir (Anadolu Şeker, 1933; Turhal Şeker, 1934).

Bu tarz milliyetçi vurgular birçok işletme ve kuruluş için yapılmış ve her ticari faaliyet, kurulan cumhuriyet rejimi ve Türklükle ilişkilendirilmiştir. Celal Bayar'ın, Nazilli kombinasının temel atma töreninde söyledikleri, bu algiyı açık bir şekilde göstermektedir. "Türk ulusu dünyanın herhangi bir ulusu ile her sahada boy ölçüşmeye muktedirdir. Cumhuriyet rejimi sizin rejiminizdir." (1935, s.116). Öte yandan büyük ölçüde azınlıklar ve onların yönetimindeki ticari faaliyetleri de içeren söylemler söz konusu millilik vurgusunun içinde sıklıkla kullanılmıştır. Örneğin ticari amaçla 1922 yılında kurulan Türkiye Milli İthalat ve İhracat A.Ş.'nin verdiği ilan şirketin en başında kuruluş nedenini ortaya koymaktadır. Ermeni ve Rumları kastederek “Türk'ün ek- 
meği ile büyüyüp, Türk vatanına kazandıkları paralarla kurşun atıp, Türkiye'nin ve Türk'ün mahvına çalışan" azınlıklara karşı, cumhuriyet kurulduktan sonra ülkeye geri dönmelerini istemeyenleri "acele hisse almak için" şirkete davet etmektedir. "İstiklal uğruna dökülen kanların boşa gitmemesi için milli şirketler kurulması çok sayıda ilana konu olmuştur." (İkin, 1971, s.203).

Milli iktisat kavramının hem düşünsel olarak hem de uygulamada gün yüzüne çıktığı İttihat Terakki döneminden itibaren, gerçekleşen iktisadi faaliyetlere ilişkin bakış açısında, kolaylıkla görülebilecek benzer bir üslup egemen olmuştur. Cumhuriyet kurulduktan sonra İttihat Terakki'nin mirası olarak devam eden bu milliyetçi bakış açısı, sıklıkla eleştirilen bir söylem olarak "devlet eliyle fert zengin etmeye" kapı aralayan ve milliyetçiliği birikim sürecine bağlayan bir mekanizmaya dönüşmüştür. Bağımsızlığın iktisadi yaşamda azınlıkların yerine geçecek Türklerle olabileceği düşünüldüğü için, sürecin aktörü de belirlenmiştir. "Asri bir devletin en mühim unsuru olan millet, yekcinstir: Ekseriya aynı lisanla konuşur. ...asri bir devlet millidir..." (1925, s. 14) diyen $A k c ̧ u r a '$ da olduğu gibi hayli etnisist ögeler de barındıran bu söylem, dönemin iktisadi-politik atmosferini belirlemede ve bu arada şeker şirketlerinin kuruluş ve işeyişinde görmezden gelinemeyecek bir unsura dönüşmüştür. Cumhuriyet rejimiyle birlikte pek çok üründe ya da sanayi dalında olduğu gibi, milliyetçi bir söylemle çevrelenen faaliyetler, bir taraftan birikim sürecine meşruluk kazandırmış, diğer taraftan azınlıkların yerine geçmek için devlet desteği talep eden yeni rejimin aktörlerine, birikimlerini farklılaştırabilecekleri bir zemin yaratmıştır.

Şeker üretimini örgütleyen şirketler, Veblen' in kavramlarıyla söylemek gerekirse 'endüstri' değil, 'iş alanına' ait varlıklardır. Pek çok ayrıcalık ve muafiyetlerle donatılan şeker şirketleri devletle iç içe geçmiş bir görüntü sergilemiş ve meşruluğunu da büyük ölçüde bu yapılanmadan almıştır. Gündelik söylemde 'devlet nüfuzunu kullanma' ya da 'devlet eliyle fert zengin etme' biçiminde kendisini dışa vuran bu ilişki biçimi, devletin ve şirketlerin mimarisini tekil bir güç mekanizması içinde kaynaştırarak, simbiyoz bir ilişki ağ ortaya çıkarmıştır. Oluşturulan ağın aktörleri, milliyetçi söylemle birlikte devletin ördüğü koza içinde, geç kapitalistleşme sürecinin belirsizliklerini aşarak istikrarlı gelir akımlarına kavuşmuşlardır. Bu süreçte belirleyici olan en önemli değişken şeker fiyatları olmuştur. İncelenen dönemin büyük çoğunluğunda 'ihtikar', 'stoklanan şeker' ve 'şeker kıtlığı' şeklinde açığa çıkan 
güç ilişkileri, birikim sürecine rengini veren önemli unsurlardandır. Dolayısıyla bu çalışma, sözü edilen güç ilişkileri çerçevesinde şeker şirketlerine ilişkin tüm faaliyetlerin 'iş alanının' gereklerine göre şekillendiğini iddia etmektedir. Endüstriden farklı olarak iş alanı, birikim süreçlerinin farklılaşmış terimlerle ifade edildiği, siyasal ve ekonomik ayrımların anlamın yitirdiği ve sermayenin güç olarak tanımlandığı bir yapı arz eder.

Çalışmada öncelikle Veblen' in 'endüstri' ve 'iş alanını' temel alan 'güç olarak sermaye' teorisi incelenmektedir. Devletin konumu ve hâkim toplumsal sınıflarla kurulan ilişki biçimlerinin incelendiği bölüm, dönemin arka planına ışık tutan düşünsel haritayı ve bunun uygulamaya yansıyan biçimlerini konuya temel oluşturması için ele almaktadır. 'Şeker-güç kompleksi' başlı̆̆ını taşıyan izleyen bölüm, şeker şirketlerinin devletle kurduğu ilişkinin analiz edildiği ilk alt başlığı takiben, fiyatlar, resmî belgeler ve ortaya çıkan uygulamalarla beraber farklılaşmış birikimi somut olarak değerlendirmektedir.

\section{Güç Olarak Sermaye Teorisi}

Sermayenin maddiliği üzerine kurulu neoklasik iktisadı sorgulayan Veblen, sermayeyi maddi bir varlık olarak görmemektedir. Buna göre sermaye kapitalize edilmiş kazanç kapasitesini temsil etmektedir (Veblen, 1932, s.131). Veblen'e göre kapitalizasyon, "mülkiyete ilişkin satılabilir nesneler temeline dayanan parasal gelir akımlarının değerlemesidir." (Veblen, 1919a, s.371). Kapitalizasyonun bu tanımından hareketle sermayeyi, kazanç akımları yaratması umulan maddi ve maddi olmayan varlıklar toplamı üzerinde, nicel ve satılabilir mülkiyet hakları olarak tanımlamak mümkündür (Cochrane, 2011, s.92). Veblen'e göre üretkenlik temelinde herhangi bir somut faktöre dayanmayan tekel hakları, gümrükler ve vergi muafiyetleri gibi maddi olmayan varlıklar, garanti edilmiş gelir akımlarının en önemli temsilcisidir. Bu çerçevede, maddi olmayan varlıklar gelirlerin kapitalize edilmiş değerlerinden oluşmaktadır. Dolayısıyla bu tip bir gelir, endüstriden değil iş ilişkilerinden türetilebilmektedir. Başka bir ifadeyle, maddi olmayan varlıklardan elde edilen kazanç, endüstri ve ticaretin kısıtlanması yani 'sabotaj' yoluyla, mülkiyeti içeren belirli ilişkilerin kullanılmasının bir sonucudur. (Veblen, 1919b, s.69-71). 'Farklılaşmış avantajlar' sağlayarak düzenlilik kazanan gelir akımlarının sebebi, maddi olmayan varlıklar aracilığıyla endüstrinin mülkiyet sahipleri tarafın- 
dan kontrol edilmesidir. 'Kazanılmış hak' olarak değerlendirilen maddi olmayan varlıklar, pazarlanabilir ve satılabilir haklardan oluşmakta ve karşıllğı olmayan kazançları çoğaltmaktadır. (Veblen, 1932, s.100). Dolayısıyla hem maddi hem maddi olmayan varlıklar sermayedir. Başka bir ifadeyle her biri kapitalize edilmiş servetin parçalarıdır.

Veblen'in tüm çalışmalarında (1919a; 1919b; 1923; 1932), belirleyici olan ayrım 'endüstri' ve 'iş' kategorileridir. Buna göre endüstrinin aktörü mühendis iken iş alanını belirleyen aktör 'iş adamıdır'. Görevinin başında olmayan (absentee owner) iş adamının en önemli özelliği, kendi işini bizzat yürüten erken dönem 'endüstri kaptanının' aksine, yalnızca parasal kazanç elde etme isteğidir. Endüstrinin teknik bilgisine sahip olmadığ gibi, amacı da bu endüstrinin etkinlik ve faydasını arttırmak olmayan iş adamının görevi, endüstrinin parasal amaçlarla kontrol edilmesidir (Veblen, 1919a, s.292). Yasal bir statüyü temsil eden mülkiyetin üretim sürecinin teknik yapısıyla, ya da üretkenliğiyle bir ilişkisi yoktur. Modern ekonomik süreç ve bu süreçteki tüm ekonomik aktiviteler, iş alanının kontrolü altındadır ve modern yaşama ait pek çok ihtiyaç, iş alanının parasal gereklilikleri ve mülkiyetle koşullanmıştır. Mevcut ekonomik düzen bir fiyat sistemine dayandığ için, iş alanının bütün zorunlulukları, tamamiyla fiyatlar üzerinden şekillenir (Veblen, 1919a, s. 244, 296). Veblen'in ifade ettiği gibi $(1923$, s.89) "iş dünyasında şeylerin fiyatları, kendilerinden daha gerçektir".

Veblen' in kavramlarından hareket eden 'güç olarak sermaye' teorisi (bundan sonra GOS) 'farklılaşmış avantaj' kavramını 'farklılaşmış birikim' şeklinde ele almış ve Veblen' in kavramlarını farklılaşmış terimlere dönüştürerek, önemli bir değişikliği ortaya koymuştur. Buna göre 'birikimin farklılaşmış özü' GOS'un en önemli dayanak noktasıdır. (Nitzan, 1998, s.186). Veblen'in sabotaj kavramını genişleten GOS'a göre, 'işlerin normal seyrinde' tüm şirketlerin uyguladığı üretimi kısıtlama faaliyetleri sabotajın 'evrenselliğine' işaret ederken, 'farklılaşmış sabotaj' ise merkezde yer alan 'hâkim sermaye' grubu tarafından uygulanır (Nitzan, 1998, s.185). Sabotajin tüm şirketler için evrensel bir kural olması, şirket üretimlerinin endüstriyel çaplarıyla ilgili değil, onların üretimlerinin karlı satışlar koşuluna bağlanmış olmasından kaynaklanır. Karlı satışın alt düzeyi yani firmanın kapanma noktası ise 'normal kar' oranı ile açıklanmaktadır. 'Normal' olarak adlandırılan karın dahi var olabilmesi evrensel anlamda sabotajla mümkündür. 'Normal kar' koşulu şir- 
ketlerin üretimlerini sınırlayan bir unsura dönüşmüştür. Ekonomi literatürüne nereden eklendiği belli olmayan normal kar kavramı, bir yandan karı doğallaştırırken diğer yandan getiri oranını da 'normal' hale getirir. (Nitzan, 1998, s.186). Nitzan'a göre normal kar elde etmediği için üretim yapmak istemeyen bir şirket, sabotajın var olduğunun göstergesidir. Paradoksal biçimde normal kar, ondan asla memnun olmayan sermaye sahipleri var olduğu için söz konusudur. Dolayısıyla uygulamada sermayenin aradığı şey, 'normal' iş koşulları değildir. Ticari işletmenin temel itkisi, ortalamayı karşılamak değil, onu aşmaktır. Başka bir ifadeyle bu güdünün bir sonucu olarak, ticari faaliyetin performansı mutlak değil, göreceli terimler çerçevesinde bir anlam ifade eder (Nitzan, 1998, s.186-187). Sonuçta yaşanan süreç, ilgili ticari alana girişin kurumsallaşmış bir biçimde kısıtlanması aracilığıyla, rakiplerin engellendiği ve tek bir şirket ya da şirket koalisyonunun, normal karla temsil edilen ortalamayı aşan karlar elde etmesidir. Geleneksel 'kar maksimizasyonu' görüşü yalnızca sermayedarın kendine ait payıyla ilgilenirken, farklılaşmanın doğası diğer sermayelerin paylarını da içerir (Nitzan ve Bichler, 2009, s.247). Veblen'den farklı olarak, karın evrenselliği ve düzenliliği "farklılaşmış sabotajın" özgün kurumları aracılı̆̆ıyla mümkün olmaktadır. Farklılaşmış birikimi ve bu çerçevede kârları mümkün kılan şey, yalnızca üretimin sınırlanmasıdır. (Nitzan, 1998, s.189). Doğası gereği sınılama konseptinin tüm metotları ve içerimleri politik bir veçheye sahiptir. Kapitalizm olgunlaşırken tüm ticari faaliyetler yalnızca özel mülkiyet kurumuyla değil, yasal, geleneksel ve ideolojik davranış kodlarıyla ve bunun yanında devleti de içeren tüm kurumsallaşmış yapılarla birleşir. Kapitalizm altında endüstrinin kontrolü, hükümet politikaları, mülkiyetin korunması, eğitim, kolluk güçleri, iki ya da çok taraflı uluslararası anlaşmalar gibi daha geniş bir kurumlar setine ihtiyaç duyar. Dolayısıyla iş alanının parasal amaçları için, toplumsal üretimin kontrol gücü olarak kavranan sermaye, en geniş tanımıyla politik bağlamın d1şında var olamaz (Nitzan ve Bichler, 2000, s.80-81).

Nitzan ve Bichler, Veblen'in kapitalizasyon kavramını daha analitik ve açılayıcı hale getirmiştir. Buna göre birikimi mümkün kılan algoritma kapitalizasyondur. Kapitalizmin temel sayısal birimi fiyatlardır. Kapitalizasyon, fiyatları yaratan ve organize eden sistemin temel algoritmasıdır. Kapitalizasyon gelecekteki gelir akımlarının şimdiki değerini temsil eder. 14. Yüzyıldan 
beri uygulanan kapitalizasyon, toplumsal yapıyı belirleme gücüne 20. Yüzyılda ulaşmıştır. Günümüz kapitalizminde ileriye dönük olarak beklenen her bir gelir akımı kapitalizasyonun adayıdır (Nitzan ve Bichler, 2009, s.151-158).

Kapitalizmin gelişimiyle birlikte farklılaşmış birikimin başat aktörü şirketler olmuştur. Veblen'in karın varlık sebebi olarak gördüğü üretimin sınırlanması, şirketler aracılığıyla yapılmaktadır. Dolayısıyla şirketlerin varlık sebebi, üretimi arttırmak değil, verimlilik ve üretim miktarın kontrol altına almaktır. Şirketler, endüstriyel birimler değil iş alanına ait kurumlardır. Üretimin kendisi endüstri alanına entegre olarak gerçekleştirilen toplumsal aktivitedir. Şirketler ise farklılaşmış yasal yapılardır. Buna göre şirketler, yatırımların 'aşırı derecede' üretken olmalarını engellemek için vardır (Nitzan ve Bichler, 2009, s.250-251, 262). Ancak birikimlerini farklılaştırma gücünün, tüm şirketler için eşit ölçüde var olması sistemin doğası gereği mümkün değildir. Bu gücün kazanılması, sermayenin devletle girdiği koalisyonlarla merkezde yer alan ‘hâkim sermaye' olmasiyla mümkündür (Nitzan ve Bichler, 2009, s.315).

Öte yandan Nitzan' ın İsrail' in doğuşu ve devletin fonksiyonuna ilişkin çalışması "geç kapitalistleşme üzerine önemli ipuçları sunmaktadır. Buna göre İsrail devleti görünüşte sermayeyi kendi özerk çıkarları için kullanmış gözükmekle beraber, gerçekte var olan durum, devletin kapitalist kurum ve organizasyonların gelişimine izin veren koruyucu bir 'koza' örmüş olmasıdır. Sermaye ve devlet ilişkisi için koza ve lavraları anolojisini kullanan yazara göre, bu çift taraflı simbiyoz ilişki, her ikisinin dönüşümünde önemli bir etken olmuştur. Nitzan' göre, koza-lavraları anolojisi, yalnız İsrail için değil, sermayenin çıkarlarının kırılgan olduğu kuruluş evreleri için tüm geç kapitalist ülkelere uygulanabilir. (Nitzan, 2002, s.17).

Devletçi koza, hâkim sermayenin tohumlarını İsrail'in kuruluş evresinde atarak farklılaşmış birikimin imkanlarını yaratmıştır. Devlet ve sermaye ya da egemenlikle mülkiyet, birbirinin karşıtı değil simbiyoz bir ilişki içinde tekil bir güç mekanizmasına dönüşmüştür. Dolayısıyla Nitzan'a göre sermayenin kendisi, devletin ortaya çıkış biçimine denk düşmektedir. Gerçekte sermaye ve devlet, simbiyotik, birleşme halinde olan ve sıklıkla da birbirlerinin içinde erimiş bir yapı arz eder. Böyle bir kozanın içinde hareket eden sermaye, devlet borçları üzerinden devletin vergileme gücünü de kapitalize etmiştir. Dolayısıyla söz konusu yapılanma devletin niteliksel ve kurumsal gücünü, kapitalizasyonun nesnesine dönüştürdüğü ölçüde, devletin kendisinin de metalaştığı bir sürece işaret etmiştir. Sonuç olarak devletin kurum ve organları, 
farklılaşmış karlar üzerindeki sistematik etkisi aracılı̆̆ıyla, sermayenin işleyiş̧ mantığının yansıdığı bir yüze dönüşmüştür (Nitzan, 2002, s.14-17).

Devlet ve sermaye arasındaki söz konusu simbiyoz ilişkinin formel biçimde, daha dar kapsamll, ancak daha fazla görünür hale geldiği önemli bir örnek, Doğu Avrupa toplumlarının 1980'li yıllarda kapitalizme geçiş sürecinde yaşadığı 'karma yapılardır'. Macaristan örneğiyle Grabher ve Stark (1997) ile Stark’ın (1998) çalışmalarında gösterilen bu yapılanma, yazarlara göre devlet ve sermayenin girdiği mülkiyet ilişkilerinin basit bir 'karma ekonomi' sınıflandırmasıyla açıklanamayacağını göstermektedir. Bu durum kapitalizme geçiş aşamasında devlete ait kurumların özel şahıslara dağıtılarak, bir yandan borçlar biçimindeki şirket sermayelerinin, devlet üzerinden hem yatay hem de dikey entegrasyona dayalı mülkiyet bağları aracilığıyla merkezileştirildiği, diğer yandan oluşturulan şirketlerdeki karları da içeren aktiflerin, özel mülkiyet biçiminde dağıtıldığı bir şirket kompleksine işaret etmektedir (Stark, 1998, s. 120-132). Birbirine kenetlenmiş bir yapılanmanın işaret ettiği en önemli sonuç, 'devlet mülkiyeti' ve 'özel mülkiyet' ilişkilerinin muğlaklığıdır. Mülkiyet üzerinden yaratılan bu muğlak durum, şirketlerin hem özel hem de kamusal mülkiyet ilişkilerini ayrıcalıklı bir şekilde kullanabilme yeteneğinin en önemli dayanağı olmuştur. Özel mülkiyet ve devlet mülkiyeti biçimindeki standart ayrımları aşan sözkonusu mekanizma, sermaye ve devlet arasındaki organizasyonel sınırları belirsizleştirdiği ölçüde, aktörlere çok taraflı bir meşruiyet gücü kazandırmıştır. Bu meşruiyet gücü, söz konusu muğlak durumun 'kaynak edinme' konusunda fonksiyonel bir işlev görmesine neden olmuştur (Stark ve Grabher, 1997, s.539-540; Stark, 1998, s.136).

Geç kapitalistleşen bir ülkede bu tarz yapılanmalar tekelci yapıların hâkim olduğu son derece dar bir piyasa mekanizması içinde oluşmaktadır. Geç kapitalistleşme sürecine 'az gelişmişlik' açısından bakan Merhav (1969, s. 30), gelişmeye başlayan endüstriyel sürecin bir sonucu olarak en başından itibaren görülen tekelci yapıların yaygınlığını, ilgili sanayi branşına giriş ‘ özgürlüğü' ve 'fiyat rekabetinin' olmamasıyla açıklamıştır. Benzer şekilde Leff de, (1978, s. 673; 1979, s. 732-733) "gelişmekte olan ülkelerdeki hızlı sanayileşmenin", bu ülkelere özgü bir tekelci yapılanmaya yol açtığını belirtmiştir. Konuya Hindistan üzerinden bakan Chaudhuri'ye göre yalnızca Hindistan değil, Pakistan, Türkiye ve Filipinler' de de kapitalist gelişmenin erken bir evresinde kapitalizm tam olarak gelişmeden, "batıdan ithal edilen tekelci yapılar", birikim sürecinin belirleyicisi olmuştur (Chaudhuri, 1984, s. 23, 27). 


\section{Devletin Konumu ve Hâkim Toplumsal Sınıflarla İlişki Biçimi}

Şeker şirketlerinin de içinde bulunduğu yapıyı anlamak, merkezi devlet idaresinin dizaynı ve işleyiş biçiminin altında yatan düşünceyi belirlemekle yakından ilişkilidir. Devlet idaresiyle iç içe geçmiş şeker-güç kompleksinin mimarisi, ülke içindeki farklı toplumsal sınıfların kompozisyonu ve devletle kurdukları ilişki biçimiyle, dış dünyanın verili politik-iktisadi koşulların bir bileşkesi olarak işlerlik kazanmıştır. Söz konusu toplumsal sınıfların değişen ve yeniden yapılanan koşullara sağladıkları uyum sürecinin dayandığı düşünsel arka plan, somut düzeyde sürecin işleyişine dair önemli ipuçları sunmaktadır. Buna göre Gökalp'in cumhuriyetin kuruluş yılında kaleme aldığ çalışma, sürecin işleyişine dair, neredeyse operasyonel düzeyde, merkezi bir devlet aygıtının nasıl çalışması gerektiğini belirtmektedir: "Devletin iktisadi işlerde salahiyettar (yetkili) olması için, iptida (öncelikle) kendisinin bir 'iktisadi devlet' mahiyetine girmesi lazımdır. Bunun için de bütün devlet ricalleriyle memurların tam manasıyla iktisadiyatçı olması şarttır. Memurlarını bu noktayı nazardan intihap eden bir devlet, büyük bir şirket gibidir" (Gökalp, 1982, s.171). Akçura da (1925, s.14) benzer şekilde "Asri (çağdaş) devletler, sanayi ve ticaret şirketlerine benzerler" şeklinde açıklamalarda bulunmuştur.

"Bugünkü vaziyet-i iktisadiyemizi tahlil ile diyebilirim ki dün olduğu gibi bugün de bizde iktisadi manasiyle mütebellir (belirgin) bir sınıf meselesi mevcut değildir" diyen M. Esat Bozkurt'un aksine (Ökçün 1997, s. 220) cumhuriyetin kaynaşmış millet olmadığını anlamak için 1923 yılında düzenlenen İzmir İktisat Kongresi'ne bakmak yeterlidir. Kongrenin hazırlığı, çağrılan aktörler, yeni rejimin kadrolarının katılımı ve büyük ölçüde toprak sahipleriyle büyük tüccarların lehine alınan kararlar, toplumsal sınıflar arasındaki güç dengesini gözler önüne sermiştir. (Boratav, 2006, s. 38-43; Avcıoğlu, 1988, ss. 340-351; Yerasimos, 1989, s. 1246-1247). Bunun ötesinde kongre aracılığıyla yeni rejimin siyasi kadroları da bu sürece dahil olarak, hâkim toplumsal s1nuflarla bir konsensüs içinde olduğunu resmen göstermiştir. Bu konsensüsün meyvelerini çok geçmeden elde eden siyasi kadronun önde gelenleri ve bu arada milletvekilleri yabancı sermayenin de dahil olduğu pek çok şirkette kurucu, hissedar ve yönetim kurulu üyesi olmuşlardır (Ökçün, 1971).

Siyasal kadroların hâkim toplumsal sınıflarla girdiği bu ilişkinin aldığı biçim, buradan türeyen iktisadi faaliyetler ve şirketler, dönemin yazarları ve bazı yöneticileri tarafından sıklıkla eleştirilmiştir. Örneğin Karaosmanoğlu 
(1968, s.86) eski askeri kadroyu kastederek, bunların bir "menfaat şirketi karakterini taşımaya" başladığını ve bu eski kadronun "kimi arsa spekülasyonları, kimi idare meclisi azalıkları, kimi taahhüt işleri, kimi de türlü türlü şekillerde komisyonculuklar peşine düşmüş" olduğunu belirtmektedir. Benzer şekilde Avcıoğlu da ticaretin azınlıkların elinden Türklere geçişinde, Ankara'da nüfuzlu Anadolu tüccarlarının yanında, ticaretle uğraşmaya başlayan subay ve memurların da göz önünde bulundurulması gerektiğini söylemiştir (1988, s. 343). Aynı şekilde Aydemir de (2011, s. 545) yaşanan bu süreci şu sözlerle ifade etmiştir: "Hemen hiçbir iş aleminden gelmeyen, hemen hepsi de eski Millî Mücadele günlerinin asker, idareci yahut siyasetçi elemanları arasından türeyen bazı insanların yeni devrin iktisadi işlerini ve imkanlarım, az çok maskeli şekillerde, fakat daima Devletin nüfuzuna dayanarak, kendi menfaatlerine kullanmak çabaları olmuştu."

Dönem boyunca konuya ilişkin tartışmalarda dikkat çeken en önemli ortak noktayı, 'devlet nüfuzunun' ticari faaliyetlerde kullanımı, 'nüfuz ticareti' ya da farklı bir ifadeyle 'siyaseti ticarete alet etmek' şeklinde tanımlamak mümkündür. Atay’a göre (1980, s. 459) böyle bir dönemde "politikayı iş ve kazançtan, tıpkı dünyayı dinden, orduyu siyasetten ayırır gibi, o kadar kati ayırmak lazımdı" oysa aferistlerin bakış açısından "liberalizm demek, devletin yapacaklarını kendileri yapmak demekti". Konu hakkında pek çok örneği olan aferizmin Türkiye'de işlediğini söyleyen Aydemir, bunun da ötesinde devletin alanına giren pek çok işin içinde, benzer grupların faaliyet gösterdiğini belirtmiş̧ir (2011, s. 461). Nüfuz ticaretine karşı alınan en önemli tedbir, devlete ait mali ve sınai kurumların yönetim kurulu üyeliğinin yasaklanması olmuş ancak bu durum süreci değiştirmemiştir (Karaosmanoğlu, 1968, s.87). Benzer şekilde Aydemir de (2011, s.461) şeker şirketlerine 'devlet nüfuzu' penceresinden bakarak şirketin etrafında oluşturulan birtakım girişimlere dikkat çekmiş, özel şirket meselesinin, "Türkiye'de, devlet nüfuz ve imkanlarına arkasını dayayarak özel teşebbüsün zaferi gibi gösterilen işlerden biri" olduğunu dile getirmiştir.

\section{Şeker-Güç Kompleksinin Mimarisi}

Şeker şirketleriyle iştirak ve kredi ilişkisine giren kurumlar bankalardır. Bu bankalardan biri 1925 yılında kurulan ve 1930 yılına gelindiğinde 6,6 milyon lira sermayeli Sanayi ve Maadin Bankası'dır. Amacı sanayiye kredi vermek 
ve devlete ait kurumları şirketlere dönüştürmek olarak belirlenmiş ancak bu hedeflere ulaşamadığı düşünülerek Devlet Sanayi Ofisi ve Sanayi Kredi Bankası şeklinde iki farklı kuruma dönüşmüş ve 1933 yılında kurulan Sümerbank'a malvarlığıyla beraber devredilmiştir (Ökçün, 1973, s.442-443). Sümerbank ise daha yüksek bir sermaye ile benzer iştirak faaliyetlerine girişerek sanayi planının uygulanmasında ve plan dışı bırakılan şeker faaliyetlerinde aşağıda da görüleceği gibi aktif rol oynamıştır. Benzer şekilde Ziraat Bankası da oluşturulan pek çok şirket yanında şeker şirketlerine de iştirak etmiştir. Öte yandan şeker faaliyetlerindeki tek özel banka İzmir İktisat Kongresindeki sermaye çevrelerinin 'ana ticaret bankası' taleplerinin karşılı̆̆ İş Bankası'dır. Tıpkı banka gibi pek çok imtiyaza sahip olan şeker şirketlerinin büyük ölçüde kurucusu olarak, devletle girdiği koalisyonlarla pek çok iştirakte bulunan merkezin hâkim sermayesi İş Bankası, yeni rejimin sermaye çevreleriyle bütünleşmesinde aktif rol üstlenmiştir (Boratav, 2006, s.44).

Böyle bir atmosferde şeker şirketleri kurulması için ilk karar, 1923 yılında toplanan İzmir İktisat Kongresinde alınmıştır (Ökçün, 1997, s.336). 1925 y1lında kabul edilen 601 Sayılı Kanun'la şeker şirketi kuracaklara belli bölgelerde 25 yıl süreyle özel imtiyaz, 8 yıl istihlak resminden, 10 yıl arazi vergisinden muafiyet gibi pek çok ayrıcalık getirilmiştir (Veldet, 1958, s. 69-70). 1923 yılında kurulan ilk şirket Uşak Terakki Ziraat T.A.Ş. adındadır. Her bir hissesi 2 lira olan 50 ortaklı şirketin toplam sermayesi 300 bin liradır. Sermaye 1925 yılında 1,2 milyon liraya 1926 yılında 1,5 milyon liraya yükseltilir (Karayaman, 2010, s.15,74). Sermayenin 250 bin liralık kısmı, fabrikayı inşa etmesi için anlaşma yapılan Çekoslovak Skoda şirketine yüzde 9 faizle ve altı eşit taksitle geri alınmak şartıyla satılır (Şeker, 2015, s.76). Skoda şirketinin elindeki hisseler daha sonra Sanayi ve Maadin Bankasına devredilmiştir. Şirket 1925-1930 yılları arasında sürekli zarar ederek, 1931 yılında tasfiye edilme kararı alınmış ve borçlarına karşılık olmak üzere Sanayi ve Maadin Bankası'na, 1933 yılında Devlet Sanayi Ofisine ve aynı yıl kurulan Sümerbank'a devredilmiştir (Karayaman, 2010, s. 111,114).

1926 yılında kurulan diğer şirket İstanbul ve Trakya T. A. Ş. (bundan sonra Alpullu Şirketi) adını taşımaktadır. Şirketin kuruluş sermayesi, 500 bin lira olarak belirlenmiş, 1927 yılında 750 bin liraya, 1933 yılında 3 milyon liraya çıkarılmıştır (İstanbul ve Trakya Şeker, 1933). Sermayenin yüzde 68'i İş Bankası'na, yüzde 10'u Ziraat Bankası'na ve yüzde 22' si özel şahıslara aittir (Veldet, 1958, s.241). 1933 yılında belirlenen şehirlerde verilen tekel haklariyla 
(14162 Nolu Kararname, 1933) kurulan üçüncü şeker şirketi, 100 liralık 30 bin hisseye bölünmüş ve dörtte biri ödenmiş 3 milyon lira sermayeli Anadolu Şeker Fabrikaları T. A. Ş.'dir. Şirketin ortaklarının payları, 1,52 milyon lira İş Bankası, 725 bin lira Ziraat Bankası, 735 bin lira Sümerbank olarak belirlenmiştir. Ortak sayısının en az beş kişi olması zorunluluğuyla, Muammer Eriş ve Mümtaz Bey 10' ar bin lira ile şirkete ortak edilmişlerdir (Ankara Ticaret Odası, Dosya No, 294). Dördüncü şeker şirketi ise 1934 yılında kurulan Turhal Şeker Fabrikaları T. A. Ş. adını taşımaktadır. Şirket, belirlenen şehirlerde tekel hakları tanıyan ilgili kararnameden (15273 Nolu Kararname, 1933) sonra kurulmuştur. Diğer şirketlerden farklı olarak her biri 100 liralık 30 bin hisseye bölünmüş 3 milyon liralık sermaye ile kurulan şirketin tamamı İş Bankası'na aittir. Kurumsal olarak İş Bankası'nun sermayesi 2,9 milyon lira olup, İş Bankası çalışanı olan diğer 4 ortağa kalan sermaye eşit olarak dağıtılmıştır (Ankara Ticaret Odası, Dosya No, 294).

\section{Pasiflerin Devlet Üzerinden Merkezileşmesi Aktiflerin Dağıtılması}

Yukarıda görüldügü gibi cumhuriyetin kuruluşuyla beraber şeker şirketlerinin de içinde olduğu pek çok iktisadi faaliyet 'devletin nüfuzunu kullanma', 'siyaseti ticarete alet etme', 'devlet eliyle fert zengin etme' ya da 'nüfuz ticareti' kavramlarıyla değerlendirilmiş hatta bazen yaşananlar 'zayıf ruhlu insanların' varlığıyla açıklanmıştır. Yaşanan gelişmelere ilişkin olarak İnönü gibi bazı aktörlerin kişiler üzerinden problemi giderme çabaları süreci durduramamıştır. Sonuçta 'politikayı iş ve kazançtan' kesin çizgilerle ayırmanın nihai çözüm olacağı dile getirilmiştir.

'Siyaseti ticarete alet etme' konusunda şikayetçi olanlar, sermayenin maddi bir varlık olarak, tüm toplumsal ilişkilerden ve bu arada devletten izole bir şekilde kendinden menkul bir verimliliğe sahip olduğu ve dolay1sıyla yalnızca buradan doğan kazançların meşru olması gerektiği ön kabulünü örtük olarak varsaymaktadırlar. Oysa GOS'a göre, siyasal alan ve buradan doğan haklar, sermaye kavramına içkindir. Sanayiye değil iş alanına ait olan sermayeyi, güç olarak tanımlamak en dar tanımıyla siyasal alanı yani burada kullanıldığı tabirle 'devlet nüfuzunu' sürecin arızi olmayan ayrılmaz bir parçası haline getirmektedir. Dolayısıyla dönemin niteliksel olarak işlev gören merkezi idare ve ona bağlı tüm kurumlardan yasal olarak türeyen 
maddi ve maddi olmayan tüm varlıklar, gelecekteki gelir beklentileriyle bağlantılı bir şekilde, büyüklük ve çapına bakılmaksızın sermaye sahipleri tarafından kendi güçlerini ölçtükleri nicel büyüklere dönüştürülerek kapitalize edilmiştir. Atay'ın (1980, s. 454) yeni rejimde zengin olma hayalleri kuran eski asker ve dönemin politikacılarını kastederek, belki de içerdiği anlamı tam olarak bilmeden sarfettiği "para kazanmak için tek sermayeleri de nüfuzları idi" sözleri sermaye olgusunun ne anlama geldiğini açığa vurmaktadır.

Öte yandan iktisadi-politik atmosferi belirlemede etkin olarak kullanılan milliyetçi söylem varlıkların kapitalize edilmesinde bazen belli bir 'sermayeye' dahi sahip olmayan Türk unsurunu, farklılaşmış birikim açısından başat aktör haline getirmiştir. Milliyetçi söylem bir yanıyla ticari hayattaki azınlık etkisini kırmaya dönük girişimlerde devlet desteğini meşrulaştırmış, diğer yandan devletin çoğu durumda dolaysız biçimde gerçekleşen söz konusu desteğini görünür kılmıştır. Şeker şirketleri, söz konusu dolaysız ilişkinin saydamlaştığı en önemli faaliyet alanlarından biridir. Bu ilişkinin kapitalize edilen tekel hakları, gümrük tarifeleri gibi maddi olmayan varlıkların ötesinde, merkezi idarenin mimarisini şekillendirmede son derece etkili olduğu gözlenmektedir. Devlet, banka ve şirket sacayakları üzerinde şekillenen bir kenetlenmenin sonucu olarak, şeker etrafinda oluşturulan tüm yapılanmayı ifade etmese de, devletin mimarisiyle iç içe geçen şeker şirketlerinin kapladığ alanı göstermesi açısından Tablo 1 büyük önem taşır.

Tabloda dikkat çeken en önemli kurum İş Bankası'dır. Banka, kuruluşundan itibaren yalnızca 1930'lar boyunca şeker şirketleri dışında devletle bağlantılı ya da bağlantısız 74 şirkete 'iştirak' etmiştir. 1935 yılında yabancı bankalar hariç tüm bankaların (43 banka) iştirakleri toplamının yaklaşık yüzde 23'üne, 1938 yılında (38 banka) yüzde 29'una sahiptir. 1937 yılı itibariyle 42 milli bankanın mevduat toplamının yüzde 36'sı yalnızca İş Bankası'na aittir. Diğer yandan I. Beş Yıllık Sanayi Planını yürütmekle görevli 17 iştirakte bulunan Sümerbank ise aynı yıllarda Türkiye'deki toplam banka iştiraklerinin sırasıyla yüzde 54 ve yüzde 42 'sine sahiptir. Benzer şekilde ülke çapında 23 iştiraki olan Ziraat Bankası için iştirak rakamları ise sırasıyla toplamın yüzde 19 ve yüzde 28'idir. (Başbakanlık İstatistik Umum Müdürlüğü, 1939, s. 283296; İş Bankası Bilançosu, 1936; 1939; Sönmez, 2001, s. 127). Güç birikiminin merkezinde yer alan bir hâkim sermaye olarak İş Bankası'nın devletle girdiği koalisyonlar içinde şeker şirketlerinin ayrıcalıklı bir yeri vardır. Bankanın şeker şirketlerinin birleştirildiği 1935 yılında Türkiye Şeker Fabrikaları T.A.Ş. 
ortaklığı toplam iştiraklerinin yüzde 60'ına çıkmıştır. Aynı rakam 1938'de yüzde 51 olarak saptanmaktadır. Sümerbank ve Ziraat Bankası'nda bu oran sırasıyla yaklaşık yüzde 79 ve yüzde 59'dur. İş Bankası'nın aynı şirkete iştirak payı ise kendi ödenmiş sermayesinden yüzde 46 daha yüksektir. Yalnızca bu rakamlar bile bankaların iştirak politikasında şeker şirketlerinin yerini göstermesi için yeterlidir. Son derece önemli bir kar kaynağ ker Fabrikaları T.A.Ş.'nin toplam net karı 1938 yılı itibariyle 1,6 milyon liradır. Dikkat edilirse bu kar Ziraat bankası hariç bankaların bireysel karlarından daha yüksektir. Dolaysıyla kurulduğu günden itibaren şeker şirketi banka karlarını besleyen en önemli faaliyet alanına dönüşmüştür.

Tablo 1. Pasiflerin Merkezileşmesi Aktiflerin Dağıtılması 1938 (TL)

\begin{tabular}{|c|c|c|c|}
\hline Sermayeler, İştirakler, Karlar & İş Bankası & Sümerbank & Ziraat Bank. \\
\hline İştirakler Toplamı (1) & 14.386 .664 & 9.228 .257 & 12.420 .244 \\
\hline Banka Karları (2) & 830.290 & 672.040 & 1.820 .784 \\
\hline Banka Sermayeleri (3) & 5.000 .000 & 42.057 .360 & 30.679 .826 \\
\hline Toplam Şeker İştirakleri (4) (1934) & 5.720 .000 & 1.375 .548 & 1.124 .000 \\
\hline İstanbul ve Trakya & 1.200 .000 & - & 399.000 \\
\hline Uşak Terakki (1930) & - & 3.388 .442 & 10.000 \\
\hline Anadolu Şeker & 1.520 .000 & 735.000 & 725.000 \\
\hline Turhal Şeker & 3.000 .000 & - & - \\
\hline Şek. Fab. AŞ'ye İştirakler (5) & 7.334 .000 & 7.333 .000 & 7.333 .000 \\
\hline Şek. Fab. AŞ Kar (6) & 656.934 & 472.945 & 482.603 \\
\hline \multicolumn{4}{|l|}{ Oranlar $\%$} \\
\hline Top. Şek. İşt. (4) / Top. İşt. (1) & 39,8 & 14,9 & 9,0 \\
\hline Şek. Fb. AŞ. İşt. (5) / Top. İşt. (1) & 51,0 & 79,5 & 59,0 \\
\hline Şek. Fab.AŞ Kar (6) / Banka Karları (2) & 79,1 & 70,4 & 26,5 \\
\hline Şek. Fab.AŞ. İşt. (5) / Banka Serm. (3) & 146,7 & 17,4 & 23,9 \\
\hline Bilgi: $\quad U_{s ̧ a k}$ & Alpullu & Anadolu & Turhal \\
\hline Şirketler Birikimli Kar. (1934) & 3.453 .945 & 1.060 .521 & 310.707 \\
\hline Şahısların Şirket Payları & 660.000 & 20.000 & 100.000 \\
\hline
\end{tabular}

(Kaynak: İş Bankası Bilançosu, 1939; Ankara Ticaret Odası, Dosya No, 294; Umumi Murakabe Heyeti [UMH], 1941a, s.23-36; UMH, 1941b, s. 25; Nafiz, 1930, s. 221; UMH, 1940a, ss. 3-26; Ziraat Bankası, 1940, ss. 36-63; Karayaman, 2010, s. 51; Veldet, 1958, s. 159).

Kuşkusuz devlet kanalıyla şirketlere akan hisse senetleri şeklindeki sermaye dışında, yardımlar, krediler ya da obligasyonlar da önemli bir kaynak aktarım mekanizması olmuştur. Ancak şirketlere giden söz konusu fonların, miktar ve kaynakları hakkında detaylı bilgiler yoktur. Örneğin Alpullu şirketi 1926 yılında bankalardan yaklaşık 2,5 milyon lira borç almıştır. Ancak bu borcun nereden alındığı belli değildir. Şirket bu borcu muhtemelen İş Bankası 
veya diğer devlet bankalarından almış olabilir. Çünkü şirketin usulsüzlüklerini ihbar eden bir mektupta, belki de bu 2,5 milyonluk borçtan bağımsız olarak, İş Bankasıyla yapılan anlaşma uyarınca bankanın şirkete, yüzde 12 faizle her yıl bir milyon lira verdiği belirtilmektedir (BCA, İstanbul-Trakya Şeker, 1940, 51.335.4). Şirket 1927 yllında sermayesini 250 bin lira arttırarak, 750 bin liraya çıkarmış ve 750 bin liralık da tahvil ihraç etmiştir. "2,5 milyon liralık borcun bir milyon lirasının karşllığ bulunmuştur". Yine şirketin pasife ödediği sekiz yıllık faiz tutarı, 3 milyon liradır (Abidin, 1934, s. 63, 112). Uşak şirketi için de Sanayi ve Maadin Bankasından 1926 yılında her ay ödenecek 200-250 bin liralık avans söz konusudur. Banka şirkete iştirak ettiği pay haricinde birikimli olarak toplam 895 bin lira kredi de vermiştir. İş Bankası da aynı şirkete, fabrikayı yapan Skoda işletmesine havale edilmek üzere 20 bin dolar vermiştir (Karayaman, 2010, s.51-52). Yine Ziraat Bankası da şirkete 307,5 bin liralık bir kredi açmıştır (Veldet, 1958, s. 154).

Devletin de dahil olduğu sürekli kurulan ve yeniden yapılanan şeker şirketleri, Nitzan'ın bahsettiği (2002, s.40) "dağılımsal koalisyonlara" önemli bir örnektir. Söz konusu koalisyonlar cumhuriyet kurulduğundan beri merkezi idareden destek talep eden sermaye çevrelerine bir cevap niteliğinde olduğu ölçüde, şeker etrafında şekillenen simbiyoz bir mimariyi görünür kılmıştır. Grabher ve Stark (1997, s. 540) ile Stark' nn belirttiği gibi (1998, s. 120-132), bu tip bir mimarinin en önemli sonucu şirketlere sermaye olarak konulan pasiflerin devlet üzerinden merkezileşmesi, karları da içeren aktiflerin, şirketler hatta bazı durumlarda şahıslar arasında dağıtılmasıdır. Daha önce de bahsedildiği gibi dönem içinde sıklıkla şikâyet edilen 'devlet eliyle fert zengin etme' politikası arızi bir durum değil, şeker örneğinde görüldüğü gibi sistematik bir yapılanmaya işaret etmektedir. Üstelik bu yapılanma belirsizliklerin oldukça yüksek olduğu bir çevrede korunma sağladığı ölçüde sisteme işlerlik kazandirmıştır.

Yine Stark'ın Macaristan örneğindeki gibi, kurulan mekanizmanın bir diğer önemli sonucu, 'devlet mülkiyeti' ve 'özel mülkiyet' ayrımına ilişkin s1nırların belirsizleşmesidir. Söz konusu muğlaklık bir yanıyla milliyetçi söylem temelinde çok taraflı meşrulaştırma mekanizmasına dönüşerek 'kalkınma retoriğine' katkı yapmış, diğer taraftan sürecin aktif katılımcılarını hesap verebilir olmaktan çıkarmıştır. Başka bir ifadeyle, söz konusu yapılanmayla, şeker şirketleri aracılığıyla gücünü ve meşruluğunu sözü edilen muğlaklıktan alan, belirsizliklere adapte olabilme yeteneği güçlü, organizasyonel 
bir biçim yaratılmıştır. Ağaoğlu'nun makalenin başında bahsettiği "Türk şekerini, işte Türk toprağından" kim yapmaktadır devlet mi? özel şirketler mi? Tekeli ve İlkin'in (2009, s. 188) I. Beş Yıllık Sanayi Planının sunuş yazısına ilişkin olarak "özel kesim ve devlet kesimi dışında milli müesseseler diye bir kategorinin getirilmiş olması ilginçtir" şeklinde dikkat çektiği bu durum, söz konusu muğlaklığın milliyetçi söylem üzerinden meşrulaştırılmasına bir örnektir.

Dönem içindeki faaliyetleri “özel girişim gibi görünseler de gerçekte devlet girişimi" şeklinde değerlendiren İnsel, bu muğlak durumu tanımlamaya çalışan pek çok örnekten biridir. İnsel'e göre bu faaliyetler tüm kararları verme gücüne sahip "patrimonyal bürokrasi" tarafindan yürütülmüştür (1996, s. 139-140). Benzer şekilde şeker şirketlerinin faaliyetlerini eleştiren, fakat gelişmelerin farkında olmayan Süreyya "devlete ait şeker müesseselerinde bile" denetimden uzak "rasyonel olmayan", yetersiz ve yüksek fiyatla yap1lan şeker üretimini "bürokratik hükümetçilik" olarak suçlamakta ve yine şeker şirketlerini "devlet mülkiyeti altında işleyen sanayi müesseseleri" olarak adlandırmaktadır (Süreyya, 1933, s.11-12). Bu muğlak durum, Türkiye'de sosyal bilim alanında toplumsal sınıflardan bağımsız olarak, bürokrasiye etkin bir sinıf muamelesi yapan, hatta tüm toplumsal sinuflara eşit düzeyde baskı uygulayan, özel girişimciliğin karşısında olan 'ceberut devlet' geleneği çerçevesinde pek çok çalışmaya kaynaklık etmiştir (bkz. Buğra, 2013; Heper, 2006; Mardin, 1990). Bu kafa karışıklığını, dönemin şeker şirketlerini inceleyen çalışmalarda da görmek mümkündür. Yazarlar 1935 yılındaki birleşmeden sonra, yeni oluşturulan şirketi kastederek, doğrudan ya da dolaylı olarak "kamu şirketi" olduğunu, ya da şirketin "devletleştirildiğini" belirtmişlerdir (bkz. Damlıdağ, 2017, s.150; Mert, 2018, s.213; Karayaman, 2012, s. 87; Tekeli ve İlkin, 2009, s. 205). Fonksiyonel işlev gören böylesi bir muğlaklığa katkı yapan, bizzat İş Bankası'nın şeker organizasyonunun içinde yer almasıdır. Aynı müphem durumun bankanın kendisiyle de ilgili olduğu ve yapılan çalışmalarda bankanın kimi zaman bir 'devlet bankası' kimi zaman 'yarı resmi' bir banka olarak tanımlandığ görülmektedir (bkz. Toprak, 2001, s.8; Keyder, 1993, s.140; Kocabaşoğlu, 2001, s.31).

Şirket sermayeleri ya da borçlarının devletin farklı kurumları üzerinden merkezileşme mekanizması, devleti bir güç biçimi olarak sürecin şekillenmesinde görünür kılmıştır. Nitzan ve Bichler'in belirttiği gibi (2009, s.281), ger- 
çekte kapitalizmin işleyişi bu tip bir kenetlenme olmasa dahi, devlet ve sermayenin kaynaşıp eridiği bir güç mekanizmasına yol açmaktadır. Ancak şeker şirketlerinin özgüllüğü, sermaye ve devletten oluşan bu simbiyoz ilişkinin, daha somut bir formda şirketler ve devlet ortakllğı biçiminde ete kemiğe bürünmesidir. Bu durum, bürokrasinin toplum üzerindeki egemenliğinin aksine, çeşitli kanallardan toplumdan çekilip alınan gelir akımlarının, şirket sermayesi ya da kredi olarak özelleştirildiği bir süreçtir. Daha açık bir ifadeyle, şeker şirketlerindeki söz konusu yapılanma ve benzerleri, topluma ait birikimlerin hatta yaşamı idame ettirecek düzeydeki varlıkların bile, özel mülkiyet biçiminde parsellenmesi operasyonudur. Sermaye güç olarak tanımlandığında, gerçekte yaşanan durum, devletin vergileme gücünün kapitalizasyonu aracilığıyla (Nitzan, 2002, s.13-14), bu gücün şirket hisseleri ya da krediler biçiminde özel mülkiyete dönüştürülmesi olmuştur. Bunun da ötesinde kurulan mekanizma, sermayenin devletle kurduğu bu simbiyoz ilişkinin sabotaj yoluyla şirket karlılı̆̆ temelinde tüm toplumsal yapıyı şekillendirme gücünü ortaya koymaktadır.

\section{Güç İlişkilerinin Yansıması: Fiyat Mekanizması}

Yurtiçi fiyatların seyri ve bu fiyatların yurtdışı ile olan bağlantısı, gücün birikiminde en önemli göstergeler arasındadır. Fiyatların gösterdiği farklılaşan gelişim seyri ve buna etki eden yurtiçi ve yurtdışı mekanizmalar, gelirin yeniden dağıtımı konusunda önemli ipuçları sunar. Veblen'in belirttiği gibi (2011, s.29) sabotajın işleyişi için önemli araçlardan biri, yurtiçi fiyatları yüksek tutarak üretimi kısttlayan gümrük tarifeleridir. Bu şekilde üretimin kısıtlanarak sabote edilmesi ve kontrol altında tutulması, geliri belli çıkar grupları lehine dağıtmanın önemli araçlarından biridir. Şeker üzerinde dönem boyunca değişen oranlarda kullanılan gümrük tarifeleri genellikle kalkınma-sanayileşme retoriği çerçevesinde ve milliyetçi bir söylem aracıllğıyla meşrulaştırılmıştır. Örneğin Bayar, mecliste şekerin yüksek gümrükler sebebiyle pahalıya geldiğine ve bu yüksek rantın şeker şirketlerine kazanç sağladığı yönündeki iddialara karşı "memlekette milli bir sanayi yaratacağız, belki biraz sikıntı çekeceğiz, fakat sonunda refaha, saadete kavuşacağız... memlekette tuttuğumuz yol refah yoludur ne israf ne de ihtikar yoludur" diyerek yantlamıştır. Yine aynı tartışmada benzer bir ifade Milletvekili Halil Bey tarafından 
dile getirilmiştir: "Sanayiyi korumak meselesi memleketin mevcudiyeti meselesi memleketin istiklali meselesidir" (TBMM, Dahili İstihlak Vergisi, 1934, s.103-106).

Gümrük politikası yurtiçindeki fiyat düzeyine doğrudan etki etmesi sebebiyle dönem içinde farklı ürünlere ve dolayısıyla farklı çıkar gruplarına avantaj sağlamış fakat aynı zamanda süreçten doğrudan etkilenen dezavantajlı toplumsal sinıflar da yaratmıştır. Tekstil, un ve şekerden oluşan 'üç beyaz' söyleminin, un dışındaki iki maddesinin yüksek gümrüklerle korunduğu gözlenmektedir. Buna göre 1916 yılıyla kıyaslandığında şeker üzerine konulmuş gümrük vergisinin artış oran 1929 yılında yüzde 615,8 olarak gerçekleşirken, aynı oranın un için yüzde 17 azaltıldığı gözlenmektedir (Kurmuş, 1978, s.197). Kurmuş'un başka bir çalışmasında belirttiği gibi (1977, s.5) Lozan'ın gümrükler konusunda bağlayıcı hükümleri sebebiyle sanayinin korunamadığı iddiasının aksine, Türkiye devlet tekeline alınan ürünlerde tarifeleri serbestçe belirleme imkânı varken, birkaç ürün dışında bu hakkı kullanmamıştır. Söz konusu az sayıdaki üründen bir tanesi şekerdir ve inhisar kanunu çıkmadan önce yüz kilosu üzerinden 18,80 lira vergiye sahiptir. Şeker inhisar kanunuyla şeker üzerindeki gümrük vergisi toplamı, kilo başına var olan 18,80 kuruşa ek olarak, zam yapılan 8 kuruş inhisar resmidir (TBMM, Şeker İnhisarı Hakkında, 1926, s.10). 1929 tarifesi şeker inhisarını kaldırarak kabaca verili durumu korumuş ve bu vergileri toplu biçimde tek bir kaleme indirgeyerek, gümrük vergisini 27,20 kuruş olarak belirlemiştir (Gümrük Tarifesi Kanunu, 1929). Bu çerçevede Tablo 2, 1926-1929 yıllarındaki şeker, şekerli ürünler ve glikoz üretim ve ithalatını göstermektedir. Tablo, İnhisar İdaresi kurulmakla beraber, ithalatın 'idare namına' tüccarlar tarafında da yapıldığını göstermektedir. İnhisar İdaresi'nin aktif olduğu söz konusu yıllara ilişkin, sonradan gazete haberlerine yansıyan yolsuzluklar dışında, detaylı bilgiler yoktur.

Tablo 2. Yurtiçi ve Yurtdışı Şeker Temini (ton)

\begin{tabular}{|c|c|c|c|c|c|c|c|}
\hline \multirow[t]{3}{*}{ Yillar } & \multicolumn{3}{|c|}{ İnhisar İdaresi Tarafından } & \multicolumn{4}{|c|}{ Tüccar Tarafından İthal } \\
\hline & \multirow{2}{*}{$\begin{array}{l}\text { İthalat } \\
\text { Şeker }\end{array}$} & \multicolumn{2}{|c|}{ Yurtiçi Üretim } & \multirow[t]{2}{*}{ Şeker } & \multirow{2}{*}{$\begin{array}{l}\text { Şekerli } \\
\text { Ürünler }\end{array}$} & \multirow[t]{2}{*}{ Glikoz } & \multirow[t]{2}{*}{ Toplam } \\
\hline & & Alpullu & Uşak & & & & \\
\hline 1926 & 23.353 & 421 & 130 & 20.147 & 212 & 528 & 44.791 \\
\hline 1927 & 755 & 4.367 & 815 & 58.414 & 343 & 1.220 & 65.914 \\
\hline 1928 & 3.671 & 3.236 & 1.299 & 70.816 & 419 & 1.127 & 80.568 \\
\hline 1929 & 1.158 & 4.807 & 3.242 & 75.729 & 412 & 654 & 86.002 \\
\hline
\end{tabular}

Kaynak: (Başvekalet İstatistik Umum Müdürlüğ̈̈̈, 1930, s. 195) 
Şeker üzerindeki gümrük vergileri, 1930'ların ilk yarısına kadar stabil kalmakla beraber, dış ticaret uygulamalarında değişikliklere gidilmiştir. En önemli değişiklik 1931 yılında çıkarılan 1873 sayılı 'kontenjan kanunudur'. Ordu Milletvekili Ahmet İhsan Bey kanuna ilişkin ihtikar ve kaçakçıllğın artacağını dile getirmiş “ihtikarın İstanbul'da arttı̆̆ını haber veriyorlar esnaf fiyatı arttırıyor" şeklinde bazı eleştiriler getirmiştir (Tekeli ve İlkin, 2009, s.225). Şeker açısından bir diğer önemli kanun ise 1932 yılında çıkarılan 2054 Sayılı (Çay, Şeker ve Kahve İthalinin, 1932) şeker ithalini takas yoluyla kontrol etmeye dönük uygulamadır. Ancak kısa bir süre sonra aynı yılın Eylül ayında çıkarılan bir kararnameyle bu yasa askıya alınmış ve şeker fiyatları yükselmiştir (Tekeli ve İlkin, 2009, s.235-236).

1934 yılında çıkarılan Dahili İstihlak vergisinin Maliye ve Bütçe Encümeni Mazbatasında gümrük vergisine ilişkin açıklamalarda bulunulmuştur. Buna göre 1933 yılında bir belediye resmi olan oktruvanın kaldırılmasıyla gümrük resmine yapılan zam sebebiyle 27,5 olan gümrük vergisi 30 kuruşa çıkmıştır. Ayrıca gelen şeker sandıklarının dara hesabı yapılmadan toplam ağırlıkları üzerinden himaye edildikleri için kabaca 32 kuruş şekerin kilosundan fiili bir koruma sağlanmış olduğu belirtilmektir. Encümenler yaptığı hesaplarla ulaştıkları sonucu şu sözlerle ifade etmiştir: "Şu hesapların delalet ettiği mana, şekerin dahili istihsal fiyatı ile satış fiyatları arasındaki farkın gittikçe fabrikalar lehine inkişaf ettiğidir" (TBMM, Dahili İstihlak Vergisi, 1934, s.2). 1935 y1lına kadar gümrük vergilerinde bir değişiklik olmamıştır. Bu tarihte çıarılan 2785 Sayılı Kanun ile şekerden alına gümrük vergisi kiloda 15 kuruşa düşürülmüştür (Şeker istihlak ve gümrük resimleri, 1935). Yine 1938 yılında çıkarılan bir kararnameyle aynı yılın haziran ayına kadar ithal edilecek küp şeker için 13,5 ve kristal şeker için 11,5 kuruş gümrük vergisi indirimi yapılmıştır (Bazı maddelerin gümrük resimleri, 1938).

Yll içinde gazetelerde, bir yandan şeker, kahve ve gaz gibi diğer ürünlerde de çeşitli yollardan fiyat yükselterek 'ihtikar' yapıldığı, diğer yandan şeker stoklarının piyasaya çıkarılmadığı şeklinde haberler yayınlanmıştır (Son Posta, 19 Şubat 1932, s.1; 20 Şubat, s.1-2; 21 Şubat, s.1, 8). Şekeri tahdit etmenin iyi bir denetim altında olumlu sonuçlar vermesi gerektiği, ancak gümrükte oluşan "fiili tröstler" sebebiyle fiyatların yükseldiği dile getirilerek "ihtikar kanununun" uygulanmasiyla, kıtlı ve fiyat yükselmelerinin ortadan kalkacağı ancak bu durumda zayıf tüccarların piyasadan çekileceği için az sayıda 
kişiye tekel kurma hakkı verilmiş olacağ dile getirilmiştir (Son Posta, 21 Şubat 1932, s.1, 8). Belediye Reisi Nuri Bey, şeker ihtikarına ilişkin denetlemenin başladığını kahvenin zorunlu bir mal olmadığı için şimdilik ilgilenmeyeceklerini bildirmiştir (Son Posta, 22 Şubat 1932, s. 8) Yine izleyen günlerde fiyatların yükseldiği ve ihtikar yapıldığına dair pek çok habere rastlamak mümkündür (Son Posta, 8 Mayıs 1932, s.1). Yine benzer bir habere göre "durup dururken ve hiç sebep yokken" şeker fiyatları yükselmeye başlamış bu durumdan sorumlu tutulan 9 şeker taciri "1913 Sayılı iktisadi koruma kanununa göre" savcıya verilmişlerdir (Milliyet, 25 Eylül 1932, s.1).

Dönemin gazeteleri ve meclis tartışmaları incelendiğinde, özellikle kontenjan uygulamasının başladığı 1932 yılında ampulden benzine, makarnadan limona, kahveden şekere, ihtikarın görülmediği mal yok gibidir. Dönem boyunca fiyat yüksekliği ve ihtikar tartışmaları hiç eksik olmamıştır. Bütçe görüşmelerinde Milletvekili Kitapçı Hüsnü ithalat yapan tüccarların sayısının azalması ve mal bulunurluğunun tehlikeye girmesiyle, pahalılığın olduğunu belirterek, "şeker ve kahve ihtikarı bariz bir şekilde gözükmektedir" şeklinde açıklamalarda bulunmuş ve şeker fiyatlarının belirlenme şeklini eleştirmiştir (TBMM, İktisat Vekaleti Bütçesi, 1933, s. 164-167).

Memlekette şeker ithali menedildiği zaman fabrikalarımızın, şekerin fiyatın lüzumsuz yere 2 kuruş tezyit ettikleri görüldü. Geçen sene 34,5 kuruşa satılan şeker bu sene 36 kuruşa çıkarıldr. Memlekete hariçten şeker gelseydi bu tezayüt olmayacaktı. Geçen sene şeker üzerine bir resim zammedilmesi demek değildi ki, ey fabrikalar, siz de fiyatlarımıza iki kuruş zam yapın. Bu, böyle olsaydı Avrupa'dan ve sairden şeker gelecekbuna lüzum kalmayacaktı... Fabrikalarımı çok milli olduğu, hatta birisi Deolete ait olduğu halde nedendir bilmem, böyle milletin sırtına yüklenerek yürüyen bu fabrikalar milletin aleyhine fiyata zammediyorlar. Ben Uşak şeker fabrikasının bir memuru ile görüştüğ̈̈̈m zaman; biz şeker piyasasına hâkim değiliz, fiyatları Alpullu fabrikası tespit eder dedi.

Kitapçı Hüsnü'nün açıklamaları, Merhav'ın "karma işletmeler" konusunda belirttiği (1969, s.155) durumun da ötesinde, tamamen devlete ait olan Uşak Fabrikasının "sanki devletin bir kurumu değilmiş gibi" piyasa koşullarının dikte ettiği fiyat ve üretim şartlarına, dolayısıyla Alpullu Şirketi'nin başat aktör olduğu bir yapılanmaya kayıtsız şartsız dahil olduğunun açı bir ifadesidir. Mecliste bu tartışmalar olurken, aynı yıl basına yansıyan haberlerde yine ihtikardan bahsedilmektedir. Ancak ihtikarın varlı̆̆ını önce tespit edip daha sonra olmadığına kanaat getiren, bunu teyit etmek için üst mercilere danışan 
sonuçta olmadığına karar veren devlet görevlileri çoğu zaman kararsız kalmış gazeteler de ihtikar konusunda birbirinin tam tersi haberleri yayınlamışlardır. (Cumhuriyet, 3 Temmuz 1933, s.5; 9 Temmuz 1933, s.1-2; 11 Temmuz 1933, s.3; 17 Temmuz 1933, s.4; 20 Temmuz 1933, s. 4; 21 Temmuz 1933, s. 5; Milliyet, 11 Temmuz 1933, s.3; Son Posta, 10 Temmuz 1933, s.2; 15 Temmuz 1933, s.3).

Yüksek fiyatlar ve onunla bağlantılı ihtikar konusundaki algılar adeta paranoid bir bozukluğa dönüşmüştür. Veblen' in $(1904$, s. 34) iş dünyası için söylediği kronik endişe hali, dönem boyunca daha avantajl konumda olmak isteyen ve sürekli birbirini suçlayan tüccar, toptancı, perakendeci ve bilumum iş alanındaki aktörlerin yaşadıkları, Nitzan ve Bichler' in belirttiği (2000, s.84) merkezin dışında yer alan aktörler arasındaki keskin rekabetin bir yansıması olarak, güç ilişkilerinin bir tezahürüdür. Daha alt düzeydeki devlet kurumlarının paralize olduğu bu süreçte, her bir aktörün amacı, pazardan diğeri aleyhine daha yüksek pay almaktır. Güç ilişkilerinin en sayılabilir biçimi olan fiyatlar üzerinden çatışan ve sürekli birbiriyle mücadele içinde olan aktörler, merkezde yer alan ve devletle girdiği koalisyonlar aracilığıyla, hâkim sermaye olarak şeker fiyatını belirleyen Alpullu Şirketi'nin kontrol ettiği ilişki ağı içinde, kendi paylarına düşeni arttırma mücadelesi vermiş̧lerdir. İhtikar söylemi üzerinden şekillenen bu kargaşa durumundan en fazla kazanç sağlayan ise merkezin tartş̧ılmaz aktörü Alpullu Şirketi olmuştur. Aşağıdaki grafik yurt içinde yaşanan bu kargaşa halinin bir yansıması olarak, dünya genelindeki şeker fiyatlarının seyrini Londra ve New York şehirleriyle karşılaştırmalı olarak vermektedir. 


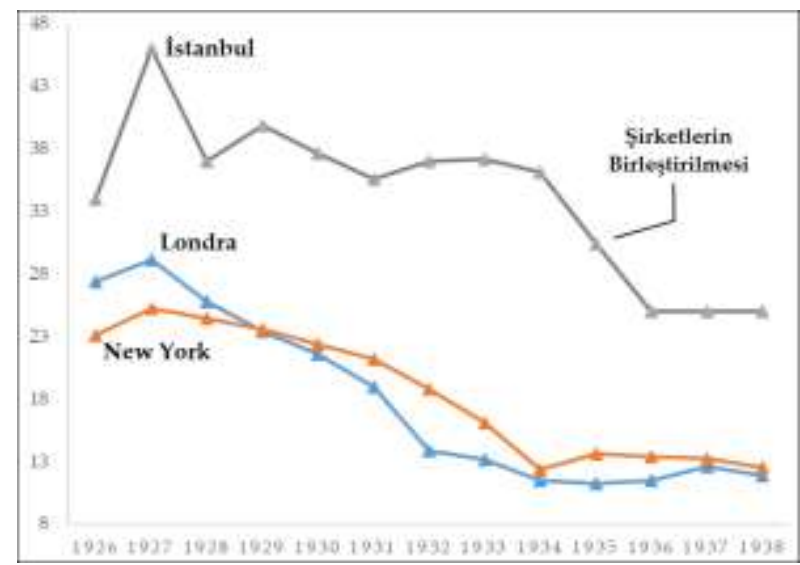

Grafik 1. Şeker Fiyatlar, Toptan, Kuruş, (Kaynak: Başvekalet İstatistik Umum Müdürlüğ̈̈, 1941, s. 425; Statistischen Reichsamt, 1929-1939)

Şeker üretimi konusunda benzer bir kargaşa kabaca 1920'lerin ikinci yarısında itibaren dünyada da yaşanmıştır. Bir yandan dünya şeker stokları artarken diğer yandan fiyatlar keskin bir şekilde düşüşe geçmiştir. Uluslararası düzeyde fiyatlar "şeker üretiminin sınırlanmasını" sağlayamadığı için çeşitli antlaşmalar yapılmıştır. Dünya şeker fiyatlarının ortalama olarak 1924-1929 arasında yüzde 20 ve 1930'larda ise yüzde 27 düştüğü bu süreçte (Albert ve Graves, 1988, s. 8-12), Türkiye'deki rakamlar 1929-1934 döneminde ortalama olarak yalnızca yüzde 0,26 düzeyinde düşüş göstermiştir. Hatta 1932 ve 1933 yıllarında fiyatlar azalmak bir yana az da olsa artış dahi göstermiştir. 1930'ların ilk yarısında yaşanan mücadele ve gerginliklerin altında, gümrük vergileri ve yurt içi üretimin kısıtlanmasıyla sağlanan sabotaj faaliyeti yatmaktadır. Yukarıda da görüldüğü gibi ortaya çıkan tepkilere hükümetin cevabı, şirketleri birleştirerek fiyatları düşürmek olmuştur. 1935 yılında fiyatlar ortalama olarak yüzde 15 düzeyinde düşüş göstermiştir. Konuya göreli fiyatlar çerçevesinde bakıldığında, aşağıdaki grafik yurt içi perakende şeker fiyatlarıyla buğday ve pancarın alış fiyatlarını göstermektedir. 


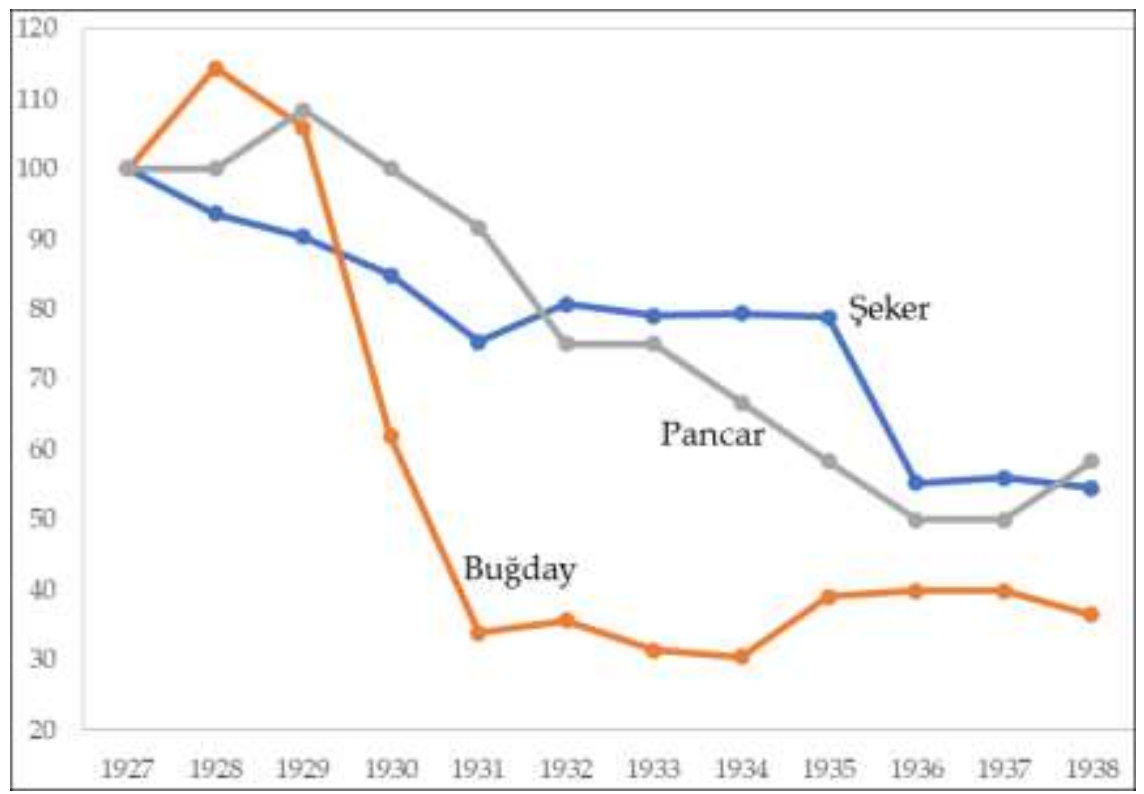

Grafik 2. Şeker, Pancar ve Buğday Fiyatlan (Perakende, kg, kuruş) (Kaynak: Bulutay, Yıldırım ve Tezel, 1974, Tablo ek 1, 10; Hatipoğlu, 1936, s.56; Başvekalet İstatistik Umum Müdürlï̈̆̈̈, 1941, s. 430)

Maddi üretime katkı sağlamaksızın, fiyat artışları üzerinden tekel hakları ve gümrükler gibi maddi olmayan varlıklar aracılığıyla karşılığı olmayan 'kazanılmış hakların' kapitalize edilmesine imkân tanıyan bu süreç, şeker şirketlerinin uyguladığı sabotajla mümkün olmuştur. Şirketler, karşılığında hiçbir bedel ödemeden sahip oldukları 'kazanılmış haklar' aracılığıyla toplumsal olarak belirlenen gelir akımlarına başkalarının aleyhine el koyma gücüne kavuşmuşlardır. Nitzan'ın "kapitalize edilen şey üretebilme gücü değil el koyma gücüdür" şeklinde belirttiği gibi $(1998$, s.183) sürecin yükünü başkalarına aktarabilme gücüne kavuşan şeker şirketleri, yukarıdaki fiyat grafiğinden de görüldügü gibi, el koyma operasyonunun maliyetini büyük ölçüde toplumun en alt kesimini temsil eden buğday üreticilerine yüklemiştir. Yaşanan sürecin en önemli meşrulaştırıcısı 'milli sanayiyi' koruma söylemi olmuştur. Bu durum aynı zamanda ihtikar biçiminde kendini göstererek fiyatlar üzerinden gerçekleşen güç ilişkilerini örten bir işlev görmüştür. 


\section{Sabotajın Formel Kaynakları: Resmî Belgeler}

Sadreddin Enver gazetede yayınlanan bir yazısında şekerin de içinde olduğu mamul mallardan ihtiyaçtan fazlasını düşünmenin hatalı olacağını belirtmiştir (Milliyet, 13 Ekim 1932, s.4). Şekerle ilgili bu açıklamaları başka sanayi dallarında da görmek mümkündür. Örneğin Ali İktisat Meclisinin Ticaret Odasından istediği rapor "fabrikatörlerin" bilgisine danışılarak hazırlanacaktır. Buna göre ipek ve trikotaj sahiplerinin de içlerinde olduğu fabrikatörlerin istekleri "sanayinin kanuni bir şekilde tahdit" edilmesidir (Akşam, 28 Aralık 1932, s. 2). Bayar (1933, s.63) Sümerbank Yönetim Kurulunda yaptı̆̆ bir konuşmada "ipek sanayiinde sürprodüksiyon mevcuttur... buna engel olmak lazımdır" diyerek bu durumun ipek üreticileri için iyi olduğunu ancak sanayinin "hırpalanmasına" yol açtığını belirtmiştir. Bu haberleri takiben 1933 y1lında 2261 Sayılı yasayla sanayi teşvik kanununa ek yapılarak teşvikler üzerinden sanayinin kısıtlanması fikri yasal bir statüye kavuşturulmuştur. Kanunun üçüncü maddesinin A fikrası "memleketin ihtiyaçlarına göre o şubede fazla istihsal bulunamaması" şeklinde yasalaşmıştır (Teşviki Sanayi Kanunu, 1933). Kanuna ayrıca sözü edilen maddenin uygulanmasıyla doğacak "sorunlar" için de "satış fiyatının normal haddin fevkine çıkmasına mâni olmak üzere tedbirler almağa hükümet" yetkilidir şeklinde bir madde Bayar'ın izniyle konmuştur. Maliye encümeni mazbatası bu maddenin konulma gerekçesini açıklamıştır. Encümen, sanayi dalında imtiyazlı olarak çalışan önceki şirketlere ayrıcalıklı bir pozisyon temin edileceğini, dolayısıyla bu maddenin "normal karı" geçen fiyat oluşumuna engel olmak için konduğunu belirterek, "hükümete maliyet fiyatına normal kâr zammederek fiyat tayin etmek ve diğer münasip tedbirler alabilmek" yetkisini verdiğini ifade etmiştir (TBMM, Teşviki Sanayi Kanununa, 1933, s.4).

1939 yılında çkarılan 3696 Sayılı yasanın gerekçesi ve İktisat Encümeni Mazbatası, kaldırılan 2261 Sayılı Kanun hakkında, yasanın uygulanmasına ve yol açtı̆̆ sorunlara ilişkin önemli bilgiler vermektedir. Gerekçede söz konusu uygulama çerçevesinde kurulan şirketlerin ürün fiyatlarının normalden yüksek olduğu tespiti yapılmıştır. Mazbata ise konu hakkında daha detaylı bilgiler vermektedir. Buna göre "fazla üretim" denetiminin yapılmasının mümkün olamadığı "takribi hesapla dahi sürprodüksiyon hesabı yapmanın kolay olmadığı" ve bunun yerine "idari bazı tedbirlerle" işlem yapıldığı ve 
bu sebeplerle de kanunun fiili olarak uygulanmadığı, ancak "asıl mühim büyük sanayi şubelerinden birkaç tanesi de resmi veya yarı resmi birkaç müesseseye inhisar etmiş" olduğu belirtilerek, "hususi teşebbüsler de bu sahada beklenilen inkişafı" göstermemiştir şeklinde açıklama yapılmıştır. Bunun da ötesinde encümen tarafından eklenen maddeyle, kanunun üretimin kısıtlandığı sanayide kurulu şirketlere sağladığı avantajın, "normal karı" aşmasını engellemek için fiyat denetimi önerisine rağmen, uygulamanın sürdüğü beş buçuk yıl boyunca encümenin endişelerinin maalesef haklı çıtığı ve söz konusu "fiyat narhının" uygulanamadığı belirtilmiştir. Eleştirilen kanun kastedilerek, yeni kurulacak şirketlere "koyduğu engel kâfi değilmiş gibi" 1938 y1lında çıartılan 3537 Sayılı Kanun'la da eskiden var olan fabrikaların genişletilme ve nakillerine de aynı kısıtlamaların getirildiği tespiti yapılmıştır. Yine mazbatada "maliyet ve normal kâr hesapları gibi çok karışık ve zor işleri" yapabilecek bir teşkilat bulunmadığı için fiyat denetiminin mümkün olmadığı dile getirilmiştir. Sonuçta "hususi teşebbüsün yeni sanayi işlerine girmesine mâni olan ve eski sanayiye imtiyazlı bir mevki veren bu kanun, hayatı çok pahalılaştırmış" şeklinde eleştirilmiştir (TBMM, Teşviki Sanayi Kanununa müzeyyel, 1939, s.1-3).

Şeker fiyatlarının yüksekliği ve bir önceki bölümde de görüldüğü gibi hiç eksik olamayan hayat pahalılığı ve ihtikar olaylarıyla birlikte, şirketlerin elde ettiği yüksek kazanç, hükümeti sürecin meşruiyetine ilişkin açılamalar yapmak zorunda bırakmış ve buna ilişkin olarak, yurtdışından getirilen bir uzmanın yaptı̆̆ şeker faaliyetlerine ilişkin çalışmalar, rapor olarak yayınlanmıştır. G. Mikusch'un hazırladığı raporda üzerinde durduğu ve farklı ülkelerden örneklerle desteklediği en önemli argümanı "fazla üretim" meselesine ilişkindir. "Vaktü zaman ile fazla istihsalin önüne geçmek şeker sanayii siyasetinin en mühim bir vazifesidir" diyen Mikusch'a göre (1934, s.15) çiftçileri memnun etmek için hükümetlerin izlediği politikalar aşırı üretime yol açarak Küba ve Java' da felaketlere yol açmıştır. Benzer "aşırı üretim" vurgularını rapor boyunca sürdüren Mikusch (1934, s.44) Türkiye'deki şeker şirketleri için de kısıtlama önerilerinde bulunmuştur. 1933 yılının yüksek üretim düzeyine dikkat çekerek düşüncelerini "bu gibi hallerin tekerrürüne meydan vermemek için pancar ziraatının muayyen bir miktarda tahdidi icabeder... 1934-35 istatistik vaziyeti fazla istihsal noktasından çok mucibi endişedir" şeklinde ifade etmiştir. 
Fiyatların yüksekliğine ilişkin tepkiler karşısında şirketlerin birleştirilmesi ve fiyatların aşağıya çekilmesi gündeme gelmiştir. Bu amaçla 'Şeker Rasyonalizasyon Komitesi' oluşturularak 1935 yılında bir rapor yayınlanmıştır (Veldet, 1958, s. 557). Raporun temel vurgularında, komitenin adında ve hazırlanan raporun başlığında değindiği en önemli unsur 'rasyonalizasyondur'. Daha açık söylemek gerekirse "pancar ve şeker istihsalinin rasyonalizasyonu" raporun en önemli vurguları arasındadır. Çünkü şeker fiyatlarının yüksekliği "rasyonalize olmayan" bir parçalı yönetim sistemine ve işleyişine dayandırılarak meşrulaştırılmaya çalışılmıştır. Bunun yanında raporda dikkat çeken en önemli unsur 'sürprodüksiyon' kavramıdır. Yukarıda da görüldüğü gibi Bayar'ın İktisat Vekili olmasıyla resmî belgelere de giren bu kavram ve anlayış raporda da yerini fazlasıyla almıştır (Veldet, 1958, s.558-567).

Hükümetin bakış açısını da içeren ve 'İnönü Projesi' olarak adlandırılan uygulamayla, rapor doğrultusunda hareket edilerek çeşitli açıklamalar yapılmıştır. Buna göre şeker tüketiminin son derece düşük olduğu belirtilerek, "şekeri pahalılaştıran istihlakin azlığı ve istihlaki azaltan şekerin pahalılığıdır. Mesele bu bakımdan fasit bir daire içinde dönüp durmaktadır" şeklinde açılamalar yapılmıştır (Veldet, 1958, s.570). Bunun da ötesinde komitenin raporu doğrultusunda çıkarılan 2785 Sayılı Yasa, şeker tahdidini özendiren esnek bir vergilendirmeyle, yeni bir şirket altında birleştirilen şeker faaliyetlerini, üretimin kısıtlanması aracılığıyla sabote etmeyi bir kanun metnine doğrudan bağlamıştır. Buna göre yasanın getirdiği vergilendirme usulü, "İnönü Projesinde yer alan bir endişeyi, yani istihsalin istihlake nispeten daha seri artması" şeklinde ifade edilen bu 'sorunu' gidermiştir. Bu çerçevede şeker şirketinin faaliyeti yurtiçi üretim ve ithalat göz önüne alınarak planlanmıştır. Planlanan İnönü Projesine ve bu paralelde çıkarılan yasaya göre şeker miktarı arttıkça istihlak resmi artış göstermektedir (UMH, 1943, s.10; Şeker istihlak ve gümrük resimleri, 1935).

Çıkarılan kanunlar ve yayınlanan raporlar, erken dönem cumhuriyet rejiminin fiyat, kar ve şirket faaliyetlerine bakışını ve uygulamaları özetler niteliktedir. Burada dikkat çeken en önemli unsur 'fazla istihsal' kavramının, adeta doğal bir işleyişin sonucu gibi algılanmasıdır. Sonuç olarak, Nitzan 'ın (1998, s.186) Veblen'in kavramlarıyla belirttiği üretimin sınırlanması olan sabotaj ve 'normal kar' kavramı, tüm sistemin fiyat ve kar politikasının temelini oluşturarak, kapitalist kurumların ötesinde, en operasyonel düzeyde tüm 
devlet mekanizmasına sızmıştır. Başka bir ifadeyle kar kategorisini doğallaştıran 'normal kar' kavramı ve üretimin kısıtlanmasına dayalı bir anlayış, cumhuriyet rejiminin yönetici kadrosuna, hukuk kurumlarına ve sermaye sahiplerinin bakış açısına, sürecin başından itibaren içkindir. Veblen'in iş dünyasına ait kavramları, rejimin belgelerinde açıkça görülmektedir. Karın varlık sebebinin üretimin kısıtlanması olduğunu bilen sürecin aktörleri, bu durumu bir yandan 'şeker rasyonalizasyonu', diğer yandan 'halkın gereksinmeleri' ve 'milli sanayinin gelişimi' gibi kavramlarla meşrulaştırarak, şekere ilişkin tüm faaliyetleri üretimin sınırlanmasına ilişkin bakış açısıyla yönetme kabiliyetine kavuşmuşlardır. Yukarıdaki kanun metinlerinde görüldüğü gibi 'fiyat denetimi' aksi yönde, tekel haklarıyla donatılmış şirketlerin varlığına işaret ettiği ölçüde, kanun metninin diliyle söylemek gerekirse 'yarı-resmi' kurumların elinde 'inhisar eden' yani tekelleşen ve 'hususi teşebbüsün' ilgili sanayi dalına girişine engel olan bir yapıya işlerlik kazandırmıştır. Kuşkusuz söz konusu kanunların ve dönemin bakış açısının, şeker şirketlerinin faaliyetlerini sınırlayarak birikimlerini farklılaştırması için tek etken olduğunu söylemek hatalı olacaktır. Hatta böyle bir kanun çıkmasaydı dahi, şeker şirketleri sabotaj faaliyetlerini yürütebilecekleri zengin bir repertuvara sahiptir.

\section{Şeker Üzerinden Sabotaj ve Birikimin Farklılaşması}

Veblen'in bahsettiği gibi (1919b, s.73), bu denli çok sayıda tekel hakları gibi maddi olmayan varlığın yer aldığı bir sistem, üretimi sınırlamanın karlılık koşulu için zorunlu olduğunun bir göstergesidir. Örneğin bunların en önemlisi daha önce de bahsedilen ve kurulacak şirketlere önemli imtiyazlarla, muafiyetler getiren 601 Sayılı Kanun'dur. Bunun yanında Şeker İnhisarı İdaresi'nin kurulması, konjonktüre göre değişen ve şirketlere avantajlar sağlayan gümrükler ve yurtiçi vergi ayarlamalarının tümü, şirketlerin 'maddi olmayan varlıkları' olarak kapitalize edilmiştir. Grafik 3, incelenen dönem boyunca şirketlerin elde ettiği net kazancı ve şeker tüketimini kişi başı terimlerle ifade etmektedir. Aşağıdaki grafik hakkında söylenebilecek en önemli şey, kabaca 1930'ların ilk yarısına kadar sabotaj faaliyetinin keskin bir yükselişle, bir yandan karları arttırmayı diğer yandan üretimi kısıtlamayı mümkün kılmış olmasıdır. 


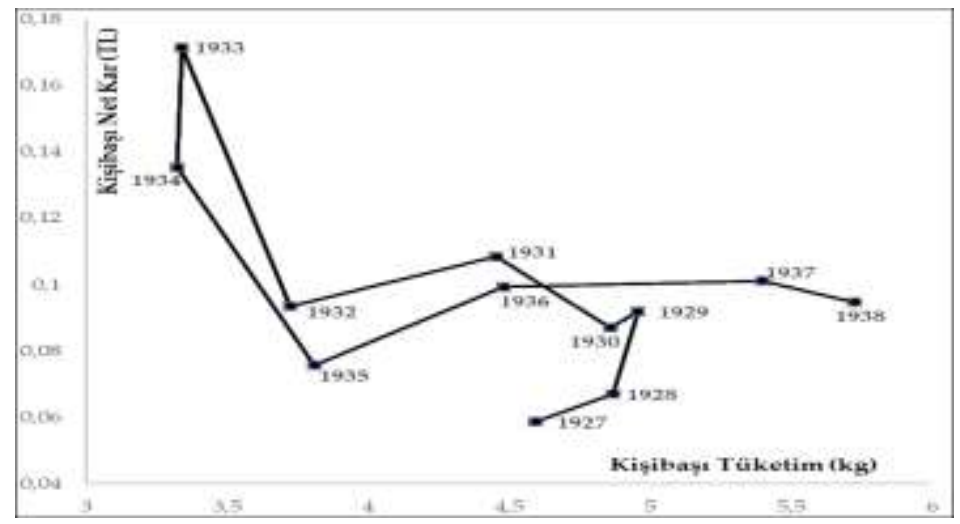

Grafik 3. Şeker-Kişi Başı Net Karlar ve Tüketim (Kaynak, Sarç, 1945, s. 300; UMH, 1941a, Ek Tablo).

Dikkat edilirse 1930'ların ilk yarısı, yukarıdaki bölümlerde de gösterildiği gibi, 'hayat pahalılığı' ve 'ihtikar' gibi kavramlarla ifade edilen bir dönemi işaret etmektedir. Gerçekte yaşanan süreç tipik bir sabotaj operasyonudur. Gazetelere yansıyan haberlere göre, süreç boyunca şeker üretimini kısıtlamak için, şirketler yüksek üretim yapsa bile, piyasaya sürülen şekerin kasıtlı olarak düşük tutulduğu anlaşılmaktadır. Söz konusu sabotaj faaliyetine yol açan bir diğer unsur gümrük politikaları olmuştur. Şeker şirketlerinin karlılığını korumanın yolu olarak kurulan gümrük mekanizması, 'milli sanayinin gelişimi' vurgusu ile meşrulaştırılarak, sürece işlerlik kazandırmıştır. Karlılığ1 korumak için sürekli iç ve dış fiyat ayarlamaları yapmayı gerektiren ve toplumsal açıdan son derece gergin bir ilişkiye dayanan süreç, dönem boyunca yaşanan sıkıntıların gerçek nedenidir. Bu durumu, yukarıda birçok örnekte gösterildiği gibi gerek meclis tartışmaları gerekse gazeteler aracılığıyla izlemek mümkündür.

Alpullu Şirketi birleşme sürecine kadar en önemli aktördür. Hatta Uşak'taki şirket tasfiye edilip, önce Sanayi ve Maaadin Bankası ardından onun yerine kurulan Sümerbank'ın eline geçtikten sonra da piyasadaki tüm fiyat ve üretim operasyonları büyük ölçüde Alpullu Şirketi tarafindan yönetilmiştir. Dolayısıyla devletin eline geçen Uşak Şirketi'nin sürece müdahil olmadığını ya da daha açı bir ifadeyle, sabotaj operasyonuna göz yumduğunu söylemek mümkündür. "Yetersiz talep" şeklinde pek çok çalışmada (Mikusch, 1934; UMH, 1941a; UMH, 1943; Veldet, 1958) yer verilen bu durum, 
sabotaj söz konusu olduğunda anlamını yitirmektedir. Şirket karlılığının en önemli kaynağı, üretimin kısıtlanması olduğu için, devlet kurumlarının resmî belgelere de yansıyan şeker üretim politikası, kısıtlama aracılığıyla söz konusu karlılık koşulunu sürekli yeniden üreten bir uygulamaya dönüşmüştür. Bu politikanın kaçınılmaz sonucu, incelenen dönemin büyük bölümünde üretim aracılığıyla herkese yetecek kadar şekerin temin edilmemesi olmuştur. Süreyya (1933, s. 15) bu duruma, "dünyanın en yüksek gümrügüyle himaye edilen şeker sanayimiz, kendini koruyan devlet bütçesine ve kendini besleyen müstahsil köylüye, dahili pazarın yüksek satış fiyatlarından doğan gelirin en mühim kısmını ödemelidir" şeklinde tepki göstermiştir.

Şirketlerin birleştirilmesiyle oluşan Türkiye Şeker Fabrikaları T. A. Ş., 'Rasyonalizasyon Komitesinin' önerisiyle var olan ayrıcalıklar korunarak ithal tekelini de eline geçirmiştir (Veldet, 1958, s.565). Bunun sonucunda şeker ithalatı birleşmeden bir yıl sonra 20,4 bin ton artarak, 22,4 bin tona çıkmıştır. Bu rakam 1937 ve 1938 'de sırasıyla 11,9 bin ile 62 bin ton olarak gerçekleşmiştir. Üretim ise birleşmeyi takip eden yıl bir önceki yıla göre 12 bin ton artmış ancak izleyen 1937 ve 1938 yıllarında bir önceki yıla göre sirasıyla yüzde 21 ve yüzde 17 düşüş göstermiştir. 1938 yılında şeker üretimi rekor düzeyde düşerek 42.527 tona inmiştir (UMH, 1941a, Ek Tablo). Aydemir (2011, s. 460) yukarıda bahsedilen ve 'İnönü Projesi' olarak adlandırılan uygulamanın sonuçlarını aşağıdaki ifadelerle eleştirmiştir:

Türkiye daha fazla fabrika kaldırmaz. Türkiye'de daha fazla fabrika kurmak için yer yoktur. Türkiye şeker eksiğini dışarıdan ithal edecektir, denildi. Son istihsal haddi 65.000 tondur, denildi. Daha fazla istihsal edersek, fabrikalar dayanamaz, dağıllır, denildi. Daha fazla istihsal edersek, gümrük gelirinden kaybederiz, denildi. Ve bu tertibe, bir de dokunulmaz isim bulundu: İnönü Projesi.

Kuşkusuz şirketlerin sabotaj faaliyetlerinin var olabilmesinin en önemli yanı rakiplerinin bulunmadığı tekelci yapılardır. Merhav'ın belirttiği gibi (1969, s.59) dar bir piyasaya sahip 'az gelişmiş' ekonomiler, ithal ettikleri üretim araçlanıla sürecin başlangıcında bile, fiili tekel haklarıyla donatılmış durumdadırlar. Şeker şirketlerinin maliyeti yüksek ithal üretim araçlarıyla, hacmi sınırlı bir piyasada kurulmuş olmaları, onların sabotaj faaliyetini daha kolay uygulayabilecekleri bir zemin hazırlamıştır. Ancak bu durum yüksek gümrük vergilerinin ve diğer tekel avantajlarının varlığıyla mümkün olmuştur. Gerek potansiyel gerekse Uşak şirketi gibi gerçek rakipler, sabotaj faali- 
yetinin gerçekleşebilmesi için engellenmiştir. Gerçekleşemese bile pek çok rakip ticari girişim, bu farklılaşmış karlardan pay almak için harekete geçmiştir. (Milliyet, 24 Nisan 1930, s. 3; 5 Haziran 1932, s. 5; Son Posta, 8 Aralık 1932, s. 3; 18 Mayıs 1932, s. 2; 23 Aralık 1932, s. 2; 31 Aralık 1932, s. 2; Cumhuriyet, 12 Mart 1934, s. 1). Söz konusu potansiyel rakipler dışında dönemin başından beri var olan tek rakip Uşak Şirketi'dir.

Pek çok çalışmada (Abidin, 1934, s. 43; Güvemli ve Karayaman, 2017, s.38, Tekeli, 1964, s. 6; Taygun, 1993, s. 92,94; Veldet, 1958, s.78, 136) değinilenin aksine Karayaman'in $(2010$, s. 69, 74, 83) ve Şeker'in $(2015$, s.63-64, 70, 79) verdiği bilgilere göre şirketin iflasındaki en etkili hususun, şirket yönetim kurulunun, Sanayi ve Maadin Bankası tarafından ele geçirilmesi olduğu anlaşılmaktadır. Şirketin iflas etmesine sebep olan gelişmelerin pek çoğu, şirkete hem borç hem de sermaye veren bankanın, yönetime etkili bir şekilde müdahil olmasından kaynaklanmıştır. Uşak şirketinin maruz kaldığı durumu Gedik (1955, s.7-8) aşağıdaki sözlerle anlatmaktadır:

Uşak Şeker Fabrikası... kuruluşunun ikinci senesinde hükümetin maşa olarak kullandığı Sanayi ve Maadin Bankası'nın insafsız kıskacıyla sarıldı, hakiki sahibinden "Uşak Terakkii Ziraat Türk anonim Şirketinden, bu şirket iflasa sürüklenmek, yüksek hararetli tasfiye potasında eritilmek suretiyle devletçilik seddi içine alındı" Uşaklılar... Hissedarlar Umumi Heyetlerinde kanun hükümlerine dayanarak hakkını müdafaa etti, fakat ne yazık ki, karşı tarafin şuursuz insafsız inadını yenemedi.

Şeker (2015, s. 45) ayrıca, Hayri İpar'1 kastederek “Şeker lobisinin alelacele, telaşla kurdukları Alpullu Şeker Fabrikasının asıl kurulma amacı ellerindeki Şeker Krallığını kaybetme duygusudur" şeklinde açıklamalarda bulunmuştur. Kuruluşundan itibaren Alpullu Şirketi'nin hem şeker fiyatlarını hem de ticaret hacmini belirlemede rakipsiz olduğu düşünüldügüunde, Uşak Şirketi'ne dolaylı yoldan müdahale etmiş olması mümkündür. Alpullu Şirketi'nin, rakiplerini eleyerek uyguladığı sabotajla beraber karları yükselmiş ve şeker üretimini kontrol edebilen tek firma olmuştur.

Alpullu Şirketi'nin 1933 yılındaki 1,2 milyon liralık yüksek karı, meclisteki tartışmalara da konu olmuştur. Yozgat Milletvekili Süleyman Sırrı, fabrikaların maliyetini hesap ederek yüzde 30-40 kar elde ettiklerini belirtmiş ve bu durumu "temettünün taksiminden gözüküyor ki bir değil 2-3 aslan payı fabrikanın kendisine kalmaktadır" şeklinde ifade etmiştir. Fabrikaların "normal bir karı" aldıktan sonra geri kalanı hükümete vermesini istemiştir. İktisat Ve- 
kili Bayar, şirketin ucuz şeker satamamasını maliyetiyle ilişkilendirmiş ve "şeker sanayiini zedeleyebilecek hareketten içtinap etmekliğimiz lazım gelir" diyerek, şirketin "normal karı" aldıktan sonra hükümetin geri kalanını alması gerektiğini prensipte kabul etmiş olduklarını ancak "hakikaten arkadaşlarımın iddia ettiği gibi, Hazinenin ve müstehlikin hakkı mevcut mudur?" şeklinde ifadelerde bulunmuştur (TBMM, Dahili İstihlak Vergisi, 1934, s.105).

İzmir Milletvekili Kitapçı Hüsnü, fabrikaların yüksek derecede amortisman ayırdığını, bunun da kazanç vergisine karşı bir uygulama olduğunu belirterek, şirketin ihtiyat akçesinin sermayesine oranla 150 bin lira yerine 874 bin lira ayrıldığını bu sebeple hazinenin alması gereken paranın 734 bin lira olması gerektiğini, yasal oranlardan fazla olan amortisman farkının da 550 bin tuttuğunu söylemiştir. Fazla amortisman ayrıldığı konusundaki suçlamalar karşısında Bayar, fabrikanın "anormal kar" elde ettiğini ve hissedarlardan birinin bu yüksek kardan "endişe ettiğini" belirterek "fabrikaya ayrllan amortismanın kâfi gelmesi şöyle dursun, yeniden tesis masrafı ayırarak fabrikayı kurmak icap edecektir" şeklinde açıklama yapmıştır. Bayar, Alpullu'daki şirket kastedilerek, bunun özel bir şirket olduğu ve vergi karşısında fiyat artışına giderek, tüketim vergisinin halka yansıtılacağı şeklindeki eleştiriyi, "hesap hususunda devlet müesseselerine yaptırdığımı onlara da yaptırırım, buna muktedirim" diyerek cevaplamıştır. (TBMM, Dahili İstihlak Vergisi, 1934, s.101-105). Yüksek kâra meclis dışından da eleştiriler gelmiştir. Örneğin Tahsin (1935, s.330-333) şeker şirketlerine ilişkin ciddi eleştirilerde bulunmuştur. Yüksek kârın bir "bilanço oyunu" olduğunu belirterek, şirketlerin yüksek amortisman, normalin üstünde sermaye faizi ve ihtiyat akçesi ayırmalarına rağmen, sabit sermayelerini arttırdıklarını, yine de yüzde 11-12 temettü dağıttıklarını ifade etmiştir.

Grafik 4, incelenen dönem boyunca 'ortalama banka kârlarını' ve bu kârların şeker şirketlerinin ortalama karlarına oranını, 'farklılaşmış birikim' şeklinde vermektedir. Şeker şirketlerinin kârlarının dönemin karlarıyla kıyaslanmasının altında yatan mantık, Nitzan'ın belirttiği (1998) ticari faaliyetin göreceli doğasıdır. Şeker şirketlerinin mutlak kârları, birikimin göreceli mantığı açısından herhangi bir anlam ifade etmemektedir. Bankaların kârlılığının dönem boyunca yüksek olduğu (Tekeli ve İlkin, 2009, s.32) ve şeker şirketleri bilançolarında kârları düşük tutmak için çeşitli yollara başvurulduğu göz önüne alınmasına rağmen, birikim sürecinin şeker şirketleri lehine bankacılık 
kesiminin karlarını bile aşan farklılaşmış doğası grafikte açıkça görülebilmektedir. 1935 yılında 'rasyonalizasyon' söylemiyle birleştikten sonra bu farkl1laşma daha da artmıştır. Gücün tek bir merkeze indirgendiği şirketlerin birleşme olgusu, farklılaşmış karları hızlandırmıştır. 1930'ların ilk yarısında uygulanan sabotaj sonucunda, gelen tepkiler ve gerginlikler sebebiyle fiyatların düşürülmek zorunda kalınmasına rağmen, farklılaşmış birikimin hızlanması, şirketlerin sürece doğrudan ve tek bir şirket üzerinden müdahil olabilme kapasitesinin artışıyla ilgilidir. Şirketlerin gücünü temsil eden bu kapasite artışı, devletle kurulan ilişkinin daha dolaysız olmasına neden olduğu gibi, şeker politikasının da detaylı bir şekilde belirlenmesine yol açmıştır. 'Rasyonalizasyon Komitesinin' istekleri ve ardından çıkan 2785 Sayılı Kanun aracılığıyla, bir yandan şeker ithalinde tekel olma gücü yeni şirket olan Türkiye Şeker Fabrikaları T. A. Ş.'ye verilirken, diğer yandan sabotaj faaliyeti, her bir ton üzerinden esnek bir vergilendirme aracllığıyla garantiye alınmıştır.

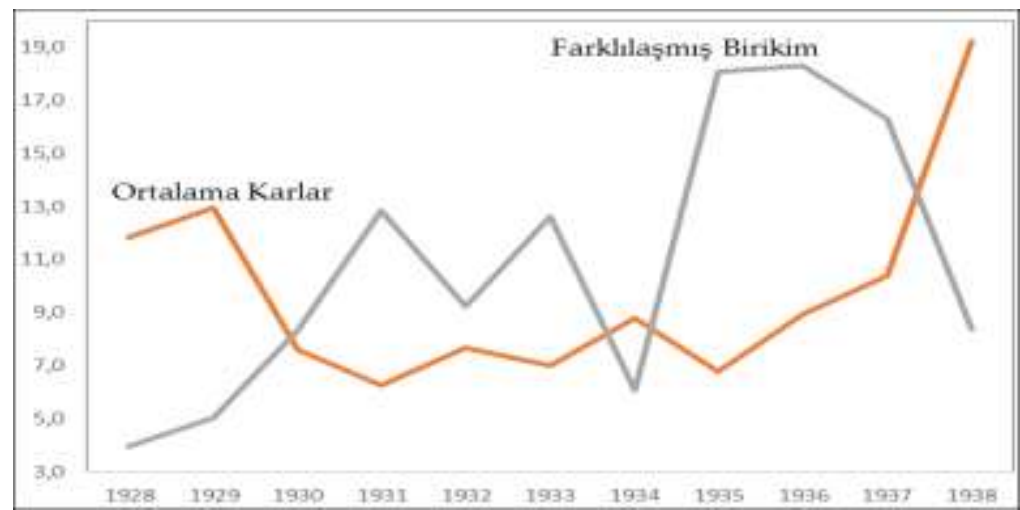

Grafik 4. Farklılaşmış Birikim ve Ortalama Kârlar

(Kaynak: Başvekalet İstatistik Umum Müdürlüğ̈̈, 1939, s. 283-297; UMH, 1941a, Ek Tablo).

Not: Ortalama Karlar: bankalar toplam karı / banka sayısı

Farklılaşmış Birikim: şeker şirketleri ortalama net karı / ortalama kârlar.

Yukarıdaki bölümde gösterildiği gibi devlet kanalıyla elde ettikleri sermayeler dışında, şirketler bankalar aracılı̆̆ıyla pek çok kredi ilişkisine de girmişlerdir. İncelenen dönem boyunca faiz oranlarının yüksekliği, döneme ilişkin pek çok açıklamada dile getirilmiştir. Gerek şirket sermayeleri gerekse kredi ilişkisi, şirket kurucularının borcu olduğu için, sabotaj faaliyetlerini zorunlu 
kılmaktadır. Nitzan ve Bichler' in belirttiği gibi (2009, s. 256-257), faiz oranlariyla sabotaj arasında pozitif bir ilişki olduğundan ve faizler de ortalama kazançları temsil ettiği için, şirketler karlarını ortalamanın üzerine çıkarmak için uyguladıkları sabotajın çapını gittikçe arttırmışlardır. Bu noktada şirketlerin 'normal kar' elde ettikleri durumda dahi, bunun kaynağının yine üretimi s1nırlamak olduğu belirtilmelidir. Ancak daima verili ortalamayı aşmaya çalışan şeker şirketlerinin amacı, hiçbir zaman 'normal kar' elde etmek olmamıştır. Dolayısıyla fiyatların yüksek tutulması ve ithalatın sınırlandırılması ya da üretimin düşürülerek, ortalamayı aşan kar oranlarıyla ithalatın artışına izin verilmesi, şirket sahiplerinin birikimlerini farklılaştırılmasına dönük bir faaliyettir. Şirketlerin faaliyetlerinin, kredi ilişkisi sebebiyle karlı olmaktan çıması, 'normal kar' ideolojisi altında kapanmaların gerektirecektir. Oysa bu durum şirketlerin sermaye ve kredi kaynağının devlet olması sebebiyle, basit bir 'iflastan' öte, tüm sistemi kırılgan hale getirebilecek sonuçlar doğuracaktır. Milliyetçi söyleme dayanan ve pek çok sabotaj faaliyetini örten 'milli sanayinin kuruluşu' şeklindeki retoriğin meşruiyeti, kapanan şirketlerle beraber ortadan kalkacaktır. Gökalp'in "devlet, büyük bir şirket gibidir" (1982, s.171) sözlerine atıfla belirtmek gerekirse, devlet şirket olmuştur, şirket de devlet. Dolayısıyla iflas gibi bir duruma izin verilmesi, merkezi idarenin kendi meşruiyetinin de sorgulanır hale gelmesine yol açacaktır. Kapitalizm koşullarında ve kurulan bu özgül kapitalizasyon sürecinde, geriye kalan tek yol, şirket karlılı̆̆yyla, fiyatları yüksek tutacak ve farklılaşmış birikimi mümkün kılacak bir sabotaj faaliyetini dönem boyunca sürdürmek olmuştur.

\section{Sonuç}

Üretilen metalar içerisinde şeker tarih boyunca önemli bir yer işgal etmiştir. Bu durum şekerin büyük ölçüde ulusal politikalarla yoğun bir etkileşim içinde olmasından, hatta onları kısmen belirleme gücüne kavuşmasından kaynaklanmıştır. Cumhuriyet rejiminin kalkınmacı retoriğinde kilit bir rol üstlenen şeker, milliyetçi söylemin ete kemiğe büründüğü bir meta haline gelmiştir. O artık sadece basit bir şeker değil, Türk'ün toprağından elde edilmiş Türk şekeridir. Ticari alandaki azınlıkların üstünlüğünü, onların yerine geçerek almayı hedefleyen Türk unsur için, topraktan üretime, oradan ticari ve siyasal yaşamın en kılcal damarlarına kendi özü gibi akan şeker, yeni cumhuriyet rejiminin milli unsurlarla yüklü kapitalist kalkınma yolunda, en cazip 
ürününe dönüşmüştür. Dolayısıyla bu tarz bir kalkınma söylemi içinde, şirketler biçiminde örgütlenen şeker üretimi, "normal zamanlarda" sıklıkla varsayılan "iktisadi" ve "siyasal" olanın ayrımına dayalı illüzyonu ortadan kaldırarak bu alanların birliğini çıplak gözle görülebilir kılmıştır. Ancak bu durum farklı bir muğlaklığa kapı aralamıştır. Politik olanla ekonomik olanın görünür hale gelen birlikteliği, devleti sürecin başat aktörü sayan pek çok çalışmaya kaynaklık etmiştir. Bahsedilen muğlaklığın altında yatan en önemli sebep, devletin içsel mimarisinin şekillenmesinde, şeker şirketleri örneğinde görüldüğü gibi iç içe geçmiş yapıların varlığıdır. Devletten bağımsız'steril bir sermaye sınıf' arayanlar ve batıdaki kapitalizmin bu ideal tipler aracilığıyla geliştiğini varsayanlar için söz konusu kenetlenmiş yapılar, devlet etkinliğinin ve gücünün belirtileri olarak yorumlanmıştır. Gerek dönemin yazarları gerekse cumhuriyet tarihine bugünden bakanlar için şeker şirketleri, bazen bir 'devlet kurumu', bazen de 'yarı resmi' işletmeler olarak algılanmış ve 'özel gibi gözüken devlet işletmeleri’ biçiminde yorumlanmıştır. Bu durum, tıpkı şeker şirketlerini büyük ölçüde kontrol eden İş Bankası'na bakışla benzer özellikler göstermektedir. Bankanın şeker faaliyetleri, şirketlerin devlet işletmeleri olarak yorumlanmasına yol açmış gözükmektedir. Bu muğlak durum basit bir yanılgıdan öte, şirketlerin faaliyetlerini milliyetçi söylem aracılığıyla meşrulaştırmada fonksiyonel bir işlev görmüştür. Görünüşte 'milli bankalar' ve onların yarattığı 'milli şirketler', el ele verip Türk şekeri üretmişlerdir. Ancak şeker şirketleri ve benzer yapılanmalarda var olan durum, bir yandan şirket sermayeleri ya da borçlarının devlet üzerinden merkezileştirilmesi, diğer yandan kârı da içeren aktiflerin özelleştirilerek dağıtılmasıdır. Başka bir ifadeyle söz konusu faaliyeti, devlet gelirleri biçiminde gözüken topluma ait varlıkların özelleştirilerek parsellenmesi operasyonu olarak adlandırmak mümkündür. Organizasyonel anlamda alışıldık yapılara benzemeyen, 'devlet' ve 'özel' ayrımını aşan bu muğlak yapılar, milliyetçi söylemin potasında eritilerek kalkınma ya da sanayileşme retoriğine katkı yapmıştır. Gücünü ve meşruiyetini söz konusu muğlaklıktan alan bu yapılanmalar, ortaklarıyla, hisse senetleriyle, bilançolarıyla ve muhasebe defterleriyle, endüstriye değil iş alanına ait varlıklardır. Şeker-güç kompleksini oluşturan ve şirketler biçiminde örgütlenen bu simbiyoz oluşumlar, milliyetçi söylemin çatısı altında çok taraflı meşruiyet yeteneği kazanarak, sayısız ayrıcalıklarla birlikte güçlerini farklılaştırmak isteyen aktörlere sistematik bir kapitalizasyon zemini ya- 
ratmıştır. İş alanına ait kapitalizasyon mekanizması aracılığıyla faaliyet gösteren şeker şirketleri, biryandan toprak, üretim araçları ve emek gibi maddi varlıklarla beraber, tekel hakları, gümrük vergileri ve vergi muafiyetleri gibi üretimin teknik doğasıyla ilişkisiz maddi olmayan varlıkları da kapitalize ederek, şeker üretimini kontrol altına almışlardır. Tüccar, toprak sahibi ya da bürokrat şeklinde ayrım gözetmeksizin yönetici kadrolarıyla, merkezi idarenin tüm organlarını sermayenin değerlenme alanına dahil eden kapitalizasyon, aynı mülkiyet haritası içinde tüm kalitatif kurumsal yapıları, sayılabilir varlıklara dönüştürmüştür.

Maddi ya da maddi olmayan varlıklar biçiminde sürekli kapitalize edilecek değerler arayarak, birbirlerini göreceli terimlerle ölçen ve 'normal kar' biçiminde tanımlanan ortalamayı aşmaya çalışan sürecin aktörleri, dönem boyunca benzerlerine sık rastlanan ve şeker-güç kompleksi biçimini alan devletin ördüğü koza içinde hareket ederek birikimlerini farklılaştırmışlardır. Veblen'e atıfla söylemek gerekirse şekerlerin kendisinden bile daha gerçek olan fiyatlar, kapitalizasyon sürecinin biricik hesaplama birimi olduğu için, yaşanan güç mücadelesinin kristalize olduğu bir görünüm sergilemiştir. Şeker şirketlerinin kurulduğu günden itibaren kişi başı şeker tüketimi 1930'ların ilk yarısında artmak bir yana düşüş göstermiştir. İthalat tekelinin ele geçirilerek şirketlerin birleştirildiği yıldan sonra yurtiçi üretimi kısmayı teşvik eden vergilendirme mekanizması aracılığıyla kurulan yeni şirket, bu kez birikimini farklılaştırmak için ithalata yönelmiştir. Sürecin başat aktörü merkezde yer alan hâkim sermaye olarak Alpullu Şirketi'nin kontrolünde geçen dönemin büyük bölümü, ithalat ve üretimin kârlı satışlar için kontrol altında tutulduğu, kesif bir sabotaj faaliyetinin ürünüdür. Yalnızca şeker üretimini değil, tüm toplumsal yapıyı şekillendiren bu süreç, bir yandan gücün dışavurumu olarak eksik olmayan ihtikar haberlerine, diğer yandan güçlerini farklılaştırmaya çalışan aktörlerin çoğu zaman gergin ve paranoid ilişki biçimlerine sahne olmuştur. Pek çoğu merkezin dışında yer alan tüccarların, toptancıların ve perakende satıcıların sürekli yetersiz kalan şeker pazarından pay kapma mücadeleleri, Alpullu Şirketi'nin belirleyici olduğu, bu gergin ilişkiler ağının bir yansımasıdır. Devletin çıkarını şirketlerin çıkarına bağlayan mekanizmaların varlığı, en azından görünür düzeyde toplumsal varlıkların devlet ve bankalar üzerinden şirket sermayelerine dönüştürülerek özelleştirildiği sürecin bir parçası olmasından ileri gelmektedir. Bu çerçevede sermaye sahiplerinin bakış açısıyla birlikte, tüm devlet kurumlarına da sızan 'normal 
kar' ideolojisi, sürekli bu belirsiz ölçüyü aşarak güçlerini farklılaştırmaya çalışan aktörlerin, sabotaj yoluyla karlı satışlarını ve yüksek fiyatları meşrulaştırma işlevi görmüştür. Milli sanayileşme retoriğini besleyen fabrikaların görüntüsü, yalnızca sermaye sahiplerine meşruluk kazandırmakla kalmamış, yeni rejimin var olma mücadelesinin de parçası haline gelmiştir. Dolayısıyla şirket sermayelerinin elde ediliş biçimi çerçevesinde merkezi idareyle şeker şirketlerini sabotaj faaliyeti ve üretimin karlılığı koşuluna bağlayan bu süreç, "asri (çağdaş) devletler, sanayi ve ticaret şirketlerine benzerler" diyen $A k$ çura'ya atıfla söylemek gerekirse, devleti şirkete, şirketi de devlete dönüştürmüştür. 


\title{
EXTENDED ABSTRACT
}

\section{Refined Power: Sugar Companies in the Early Republican Period as the Site of Contest}

\author{
Özgür Çetiner \\ Bilecik Şey Edabali University
}

Many commercial activities also involving the sugar companies were surrounded by a severe nationalist discourse and the emphasis of Turkishness. In the perspective regarding economic activities as of the era of the Committee of Union and Progress, when the concept of 'National Economy' came to light both ideationally and in practice, a similar discourse has been realized as predominant. Such a nationalist perspective taken over from the era of the Committee of Union and Progress after the Republic was established turned into a mechanism connecting nationalism to the process of accumulation to the extent of its contribution to the discourse 'enriching individuals by favor of the state' frequently criticized. Since freedom was thought to be possible with Turks who would replace minorities in financial life, the actor of the process was also determined. This discourse including quite ethicist elements became an unignorable factor in terms of determining the financial-political atmosphere of the era and in the establishment and functioning of sugar companies. Activities surrounded by a nationalist discourse along with the Republican regime as it was with many products and in the field of industry both legitimized the process of accumulation and provided the ground where the actors of the new regime could differentiate their accumulations.

The companies organizing sugar production are not the assets of the 'industry' but the 'business' as stated by Veblen. Many sugar companies having various privileges and exemptions have been observed to be intertwined with the government and have owed their legitimacy mostly to this structuring. This form of relationship expressed as 'exerting the state's influence' or 'enriching individuals by favor of the state' combined the architecture of the state and the companies in a single power mechanism and revealed a symbiotic net of relationship. The actors of the net created have attained consistent revenue streams by overcoming the uncertainties of late capitalization pro- 
cess within the cocoon that the state spun together with the nationalist discourse. The most important variable being definitive has been the sugar prices during this process. In a great majority of the period examined, the power relations revealed in the form of 'engrossing', 'stocked sugar' and 'sugar shortage' are among the important factors shaping the accumulation process. The fundamental factor in such an operational activity has been the structuring in the form of company shares.

As Veblen have stated, the category of profit became natural rather than being a coincidence and formed the basis of regular revenues to the extent that the institution of property that has gained an absolute entity together with capitalism provided the opportunity of sabotage as the power to inhibit production to its owners. According to Veblen, who defined capital as capitalized capacity of gain in its most general sense, capitalization is the appraisement of monetary revenue streams based on sellable objects. According to this definition of capitalization, it is possible to define capital as quantitative, sellable property rights on total tangible and intangible assets creating income streams. The theory of 'capital as power' considering Veblen's concepts addressed the concept of 'differential advantage' as 'differential accumulation' and revealed a theoretically significant change by transforming Veblen's concepts into a differentiated terms. Accordingly, the differentiated origin of accumulation is the most important reference point of the capital theory. Within this context, the concept of 'normal profit', available in the literature of economics has served as a scale that constitutes the foundation of differential accumulation as a category of profit where capital owners measure their powers and constantly try to surpass. Therefore, the basic motive of enterprises is not to meet the average but to surpass the average. In other words, as a result of this motive, the performance of commercial activity does not make sense within the context of absolute terms but relative terms. Since the most basic relative variable where the power is crystalized is prices, capitalization becomes the fundamental algorithm of the system creating the prices and organizing them within the scope of differential accumulation. All the discussions made regarding the highness of sugar prices throughout the period is a reflection of the accumulation process where sugar companies willing to differentiate their powers distrain communal assets through the state and banks. When it is noted by the analogy in Veblen's words, prices have turned into a more real element than sugar itself. 
The sabotage activity also reflected on the state's official documents is the most important tool making differential accumulation possible. Sabotage, the limitation of production and the concept of "normal profit" have formed the basis of the price and profit policy of the entire system and seeped into the entire state mechanism at the most operational level beyond capitalist institutions. In other words, an understanding based on the concept of "normal profit," naturalizing the category of profit and the restriction of production is implicit in the management group of the republican regime, law institutions and the perspective of capital owners as of beginning of the process. The actors of the process knowing that the raison d'être of profit is the restriction of production legitimated this situation through "sugar rationalization" and concepts such us "the needs of the public" and "the development of the national industry" gained the ability to manage all activities regarding sugar with the viewpoint regarding the restriction of production. The sabotage activity and differential accumulation became possible with the coalitions of companies within the state. The formations similar to the sugar companies have mostly been at the center of the process as "the dominant capital." These complicated structures, not like the familiar structures in the organizational sense and surpassing the "state" and "private" distinction, have been intertwined within the nationalist discourse and have contributed to the rhetoric of progress or industrialization. The company activities legitimated through nationalist discourse have created a specific capitalization mechanism within the process of 'late capitalist development'. By making a reference to Akçura noting that "modern states resemble industry and trade companies", the capitalization process, connecting the benefits of the central administration to the benefits of the company within the framework of interwovenness of sugar companies has turned states and companies into a single power mechanism with the same understanding.

\section{Kaynakça / References}

14162 Nolu Kararname. (1933, 24 Nisan). Resmî Gazete (Sayı: 2383). https://www.resmigazete.gov.tr/arsiv/2383.pdf adresinden erişilmiştir.

15273 Nolu Kararname. (1933, 27 Kasım). Resmî Gazete (Sayı: 2563). https://www.resmigazete.gov.tr/arsiv/2563.pdf adresinden erişilmiştir. 
28 Mayıs 1927 tarih ve 1055 numaralı teşviki sanayi kanununa müzeyyel kanun. (1933, 8 Haziran). Resmî Gazete (2422). https://www.resmigazete.gov.tr/arsiv/2422.pdf adresinden erişilmiştir.

Abidin, İ. (1934). Şeker yitirmeden bitirmeye kadar Türkiye-dıs memleketler. İstanbul: Akşam Matbaası.

Akçura, Y. (1925). Asrî Türk Devleti ve münevverlerine düşen vazife. Türk Yurdu, 17(174), 13-20.

Albert, B. ve Graves, A. (1988). Introduction. B. Albert And A. Graves (Der.), The world sugar economy in war and depression, 1914-40 içinde (s. 1-25). London: Routledge.

Anadolu Şeker Fabrikaları Türk Anonim Şirketi Esas Mukavelesi. (1933, 30 Aralık). Resmî Gazete (Sayı: 2591). https://www.resmigazete.gov.tr/arsiv/2591.pdf adresinden erişilmiştir.

Ankara Ticaret Odası. (1933). Anadolu Şeker Fabrikaları Türk Anonim Şirketi. Arşiv Dosya No: 294.

Ankara Ticaret Odası. (1934). Turhal Şeker Fabrikası Türk Anonim Şirketi. Arşiv Dosya No: 294.

Atay, F. R. (1980). Çankaya. İstanbul: Sena Matbaası.

Avcıoğlu, D. (1988). Türkiye'nin düzeni dün bugün yarn, 1. cilt.Istanbul: Tekin Yayınevi. Aydemir, Ş. S. (2011). İkinci adam I. Cilt (1884-1938). İstanbul: Remzi Kitabevi.

Aykut, Ş. (1935). Alpullu nasil kuruldu. Alpullu Dergisi, 1(5), 1-3.

Başvekalet İstatistik Umum Müdürlüğü. (1930). İstatistik Ylllı̆̆̆ Cilt 3. İstanbul: Ahmet İhsan Matbaası.

Başvekalet İstatistik Umum Müdürlüğü. (1939). İstatistik Yıllığı Cilt 10. İstanbul: Hüsnü Tabiat Basımevi.

Başvekalet İstatistik Umum Müdürlüğü. (1941). İstatistikyıllı̆̆ı cilt 12. Ankara: Ankara Basım ve Ciltevi.

Bayar, C. (1933). Celal Bayar'ın Sümerbank idare meclisinde yaptı̆ı konuşma. Ö. Şahingiray (Der.), Celal Bayar'n söylev ve demeçleri 1921-1938 ekonomik konulara dair içinde. (s. 61-67). İstanbul: Türkiye İş Bankası Kültür Yayınları.

Bayar, C. (1935). Ekonomi bakanı Celal Bayar'ın Nazilli kombinasını temel atma merasimindeki söylevi. Ö. Şahingiray (Der.), Celal Bayar'in söylev ve demeçleri 1921-1938 ekonomik konulara dair içinde. (s. 115-116). İstanbul: Türkiye İş Bankası Kültür Yayınları.

Bazı maddelerin gümrük resimleri hakkında hükümetçe ittihaz olunan kararların tasdikine dair kanun. (1938, 2 Mayıs). Resmî Gazete (Sayı: 3896). https://www.resmigazete.gov.tr/arsiv/3896.pdf adresinden erişilmiştir. 
Boratav, K. (2006). Türkiye'de devletçilik. Ankara: İmge Yayınları.

Buğra, A. (2005), Devlet ve iş adamları. İstanbul: İletişim Yayınları.

Bulutay, T., Yildırım, N. ve Tezel, Y.S. (1974). Türkiye milli geliri (1923-1948) Tablolar. Ankara: Sevinç Matbaası.

Chaudhuri, A. (1984). Monopoly capitalism in a dependent economy: the Indian case. Social Scientist, 12(1), 14-29.

Cochrane, D. T. (2011). Castoriadis, Veblen and the 'power theory of capital'. J.F. Humphrey ve I. S. Straume (Der.), Depoliticization: The Political Imaginary of Global Capitalism içinde (s. 89-123). Malmö: Aarhus University Press.

Şeker pahalılığı ile mücadele. (1933, Temmuz 11). Cumhuriyet. 3.

Şeker fiyatları. (1933, Temmuz 17). Cumhuriyet. 4.

Şeker fiyatlarında ihtikar var mı yok mu?. (1933, Temmuz 20). Cumhuriyet, 4.

Şeker ihtikarı var mı yok mu?. (1933, Temmuz 21). Cumhuriyet, 5.

Şeker fiyatlarının tetkiki. (1933, Temmuz 3). Cumhuriyet. 5.

Kesme şeker fiyatları neden bu kadar yüksek. (1933, Temmuz 9). Cumhuriyet. 1.

Cumhuriyet. (1934, Mart 12). Trakya için mühim kararlar, s. 1.

Çay, Şeker ve Kahve İthalinin Bir Elden İdaresi Hakkında Kanun. (1932, 6 Temmuz). Resmî Gazete (Sayı: 2143). https://www.resmigazete.gov.tr/arsiv/2143.pdf adresinden erişilmiştir.

Damlıdağ, F. (2017). Development of beet sugar industries in the world and the example of Alpullu Sugar Factory. Çă̆daş Türkiye Tarihi Araştırmalan Dergisi, 17(34), 133-157.

Devlet Arşivleri Başkanlığı Cumhuriyet Arşivi. Muamelat Genel Müdürlüğü. (1940, 22 Mart). İptal edilmiş olan İstanbul-Trakya Şeker Fabrikaları TAŞ hakkında yapılan ihbarın araştırıldığı ve yapılacak herhangi bir işlem kalmadığı. (3010-0-0 / 51.335.4).

Gedik, H. (1955). Uşak Şeker Fabrikasının kısa tarihçesi. Pancar Dergisi, 5(49), 7-8.

Gökalp, Z. (1982). İktisadî inkılâp için nasıl çalışmalıyız. A. Çay (Haz.), Makaleler VIII içinde (170-172). Ankara: Kültür Bakanlığı Yayınları.

Grabher, G. ve Stark D. (1997). Organizing diversity: evolutionary theory, network analysis and postsocialism. Regional Studies, 31(5), 533-544.

Gümrük Tarifesi Kanunu. (1929, 1 Temmuz). Resmî Gazete (Sayı: 1230). https://www.resmigazete.gov.tr/arsiv/1230.pdf adresinden erişilmiştir.

Güvemli, O. ve Karayaman, M. (2017). Uşak Şeker Fabrikasının kuruluşu ve gelişmesi. Accounting and Financial History Research Journal, 1(13), 6-50.

Eskişehir Şeker Fabrikası dün açıldı. (1933, Aralık 6). Hakimiyeti Milliye. 1. 
Hatipoğlu, Ş. R. (1936). Türkiye'de zirai buhran. Ankara: Yüksek Ziraat Enstitüsü Basimevi.

Heper, M. (2006). Türkiye'de devlet geleneği. (Çev. N. Soyarı). Doğu Batı Yayınları, Ankara.

İkin, S. (1971). Türkiye milli ithalat ve ihracat anonim şirketi. Ortadoğu Teknik Üniversitesi Gelişme Dergisi, 2, 199-232.

İnsel, A. (1996). Düzen ve kalkınma kıskacında Türkiye. İstanbul: Ayrıntı Yayınları.

İstanbul ve Trakya şeker fabrikaları T.A.Ş. Umum Heyetinin 26 Şubat 1933 tarihinde akteylediği fevkalâde içtimada tadil ettiği esas mukavelename mevaddı. (1933, 3 Aralı). Resmî Gazete (Sayı: 2568). https://www.resmigazete.gov.tr/arsiv/2568.pdf adresinden erişilmiştir.

İş Bankası Bilançosu. (1936, 3 Nisan). Resmî Gazete (Sayı: 3270). https://www.resmigazete.gov.tr/arsiv/3270.pdf

İş Bankası Bilançosu. (1939, 15 Nisan). Resmî Gazete (Sayı: 4184). https:/www.resmigazete.gov.tr/arsiv/4184.pdf adresinden erişilmiştir.

Karaosmanoğlu, Y. K. (1968). Politikada 45 yıl. Ankara: Bilgi Yayınları.

Karayaman, M. (2010). Nuri Şeker ve Uşak Şeker Fabrikası'nın kuruluşu. Uşak: Uşak Akademi Kitabevi.

Karayaman, M. (2012). Atatürk döneminde şeker sanayi ve izlenen politikalar. Atatürk Araştırma Merkezi Dergisi, 28 (82), 53-96.

Keyder, Ç. (1993). Dünya ekonomisi içinde Türkiye (1923-1929). İstanbul: Tarih Vakfı Yurt Yayınları.

Kocabaşoğlu, U. (2001). Türkiye İş Bankası tarihi. İstanbul: Türkiye İş Bankası Kültür Yayınları.

Kurmuş, O. (1977). Cumhuriyetin ilk yıllarında sanayinin korunması sorunu ve ticaret sermayesinin tavrı. O. Kurmuş, İ. Tekeli, S. İkin, K. Boratav, G. Tüzün, A. Börüban (Der.), Tarihsel gelişimi içinde Türkiye sanayi içinde (s. 320). Ankara: Makine Mühendisleri Odası Yayınları.

Kurmuş, O. (1978). 1916 ve 1929 Gümrük tarifeleri üzerine bazı gözlemler. Ortadoğu Teknik Üniversitesi Gelişme Dergisi, Türkiye İktisat Tarihi Üzerine Araştırmalar 1978 Özel Sayısı, 182-209.

Leff, N. H. (1978). Industrial organization and entrepreneurship in the developing countries: the economic groups. Economic Development and Cultural Change, 26(4), 661-675.

Leff, N. H. (1979). Monopoly capitalism and public policy in developing countries. Kyklos, 32(4), 718-738. 
Mardin, Ş. (1990). Türk siyasasını açıklayabilecek bir anahtar: merkez çevre ilişkileri. M. Türköne, T. Önder (Der.), Türkiye'de Toplum ve Siyaset içinde (s. 30-66). İstanbul: Illetişim Yayınları.

Merhav, M. (1969). Technological dependence, monopoly, and growth. London: Pergamon Press.

Mert, M. (2018). Kuruluş yıllarında şeker sanayi ve devletin amaç fonksiyonu. TESAM Akademi Dergisi, 5(2), 183-247.

Mikusch, G. (1934). Şeker sanayiimiz hakkında rapor. Ankara: Başvekalet Matbaası.

Yeni şeker fabrikası. (1930, Nisan 24). Milliyet, 3.

Maden ve sanayi politikamız. (1932, Ekim 13). Milliyet. 4.

9 şeker taciri müddei umumiliğe verildi (1932, Eylül 25). Milliyet, 1.

Adana' da şeker kamışı yetiştirilecek (1932, Haziran 5). Milliyet. 5.

Şeker fiyat,, (1933, Temmuz 11). Milliyet. 3.

Cumhuriyetin yeni bir eseri (1934, Ekim 20). Milliyet., 1

Nafiz, İ. (1930). Şeker sanayimiz. 1930 Sanayi Kongresi Raporlar Zabıtlar içinde (ss. 218234). Ankara: Milli İktisat ve Tasarruf Cemiyeti Yayınları.

Nitzan, J. (1998). Differential accumulation: towards a new political economy of capital. Review of International Political Economy, 5(2), 169-216.

Nitzan, J. ve Bichler, S. (2000). Capital accumulation: breaking the dualism of 'economics' and 'politics'. R. Palan (Der.), Global Political Economy Contemporary Theories içinde (s. 60-88). New York: Routledge.

Nitzan, J. ve Bichler, S.(2002).The global political economy of Israel.London:Pluto Press.

Nitzan, J. ve Bichler, S. (2009). Capital as Power. London: Routledge.

Ökçün, G. (1971). 1920-1930 yılları arasında kurulan Türk anonim şirketlerinde yabancı sermaye. Ankara: Ankara Üniversitesi Siyasal Bilgiler Yayınları.

Ökçün, G. (1973). 1909-1930 yılları arasında anonim şirket olarak kurulan bankalar. O. Okyar (Der.), Türkiye İktisat Tarihi Semineri içinde (s. 409-484). Ankara: Hacettepe Üniversitesi Yayınları.

Ökçün, G. (1997). Türkiye İktisat Kongresi haberler-belgeler-yorumlar. Ankara: Sermaye Piyasası Kurulu.

Sarc, Ö. C.(1945). Memleketimizde şeker talebi.İktisat Fakültesi Mecmuası,5(1-4),292 328

Şeker fabrikaları. (1932, Aralık 23). Son Posta. 2.

Karacabey'deki fabrikanın inşası gecikecek, (1932, Aralık 31). Son Posta. 2.

Yeni bir şeker fabrikası kuruluyor, (1932, Aralık 8). Son Posta. 3.

Bir şeker fabrikası, (1932, Mayıs 18). Son Posta. 2.

Piyasadaki şeker buhranı tamamen sunidir, (1932, Mayıs 8). Son Posta. 1.

İtikar yok diyenlere, (1932, Şubat 19). Son Posta, 1. 
Şeker değil altın ticareti yapılıyor (1932, Şubat 20). Son Posta., 1-2.

İtikar tahakkuk ediyor. (1932, Şubat 21). Son Posta, 1-8.

İtikar mücadelesi. (1932, Şubat 22). Son Posta, 8.

Şeker iş ne oluyor. (1933, Temmuz 10). Son Posta, 2.

İster inan ister inanma. (1933, Temmuz 15). Son Posta, 3.

Sönmez, S. (2001). Türkiye İş Bankası'nın "misyonu" ve iştirakçilik politikası (19241945). Mülkiye Dergisi, 25(231), 111-148.

Stark, D. (1998). Recombinant property in East European capitalism. The Sociological Review, 46(1), 116-146.

Statistischen Reichsamt. (1940). Statistisches Jahrbuch für das Deutsche Reich (1929-1940). Internationale Übersichten. Berlin: Reimar Hobbing. https://www.digizeitschriften.de/dms/toc/?PID=PPN514401303 adresinden erişilmiştir.

Süreyya, Ş. (1933). Milli iktisat planı ve şeker sanayimiz. Kadro Dergisi, 24, 5-16.

Şeker istihlak ve gümrük resimleri hakkında kanun. (1935, 17 Haziran). Resmi Gazete (Sayı: 3030). https://www.resmigazete.gov.tr/arsiv/3030.pdf adresinden erişilmiştir.

Şeker,M.(2015).Şeker dedem Uşak Şeker fabrikasının gerçek hikayesi.İzmir:Meta Basım.

Tahsin, S. (1935). Şeker sanayiimiz hakkında rapor. Dönüm, 31, 324-334.

Taygun, N. (1993). Türkşeker'in öyküsü. Ankara: Türkiye Şeker Fabrikaları AŞ. Yayın No: 217.

Tekeli, İ. ve İlkin, S. (2009). Uygulamaya geçerken Türkiye'de devletçiliğin oluşumu, İstanbul: Bilge Kültür Sanat.

Tekeli, S. T. (1964), Şeker sanayinin millet iktisadımızdaki yeri ve önemi, Ankara: Ankara Üniversitesi Basımevi.

Toprak, Z. (2001). Osmanlı'dan Cumhuriyete Sermaye Birikimi ve Kredi Kurumlarının Evrimi, 1850-1950. Active Dergisi Kasım-Aralı Özel Eki, 1-10.

Turhal Şeker Fabrikaları Türk Anonim Şirketi Esas Mukavelesi. (1934, 7 Temmuz). Resmi Gazete (2745). https://www.resmigazete.gov.tr/arsiv/2745.pdf adresinden erişilmiştir.

Türkiye Büyük Millet Meclisi Zabıt Ceridesi. (1926, 25 Ocak). Şeker inhisar hakkında muvazenei maliye encümeni mazbatası. Cilt 21, Devre 2, İçtima Senesi 3.

Türkiye Büyük Millet Meclisi Zabıt Ceridesi. (1933, 18 Haziran). İktisat Vekaleti bütçesi görüşmeleri. Cilt 15, Devre 4, İçtima Senesi 2.

Türkiye Büyük Millet Meclisi Zabıt Ceridesi. (1933, 3 Haziran). 28 Mayıs 1927 tarih ve 1055 numarah teşviki sanayi kanununa müzeyyel kanun. Cilt 16, Devre 4, İçtima Senesi 2. 
Türkiye Büyük Millet Meclisi Zabıt Ceridesi. (1934, 21 Nisan). Dahili istihlâk vergisinin hakkındaki kanunun I inci maddesinin değiştirilmesi hakkında. Cilt 21, Devre 4, İçtima Senesi 3.

Türkiye Büyük Millet Meclisi Zabit Ceridesi. (1939, 6 Temmuz). Teşviki sanayi kanununa müzeyyel 2261 sayılı kanunun 3 ncü maddesi ile 3537 sayıl kanunun I inci maddesinin son fikrasının ilgası hakkında kanun lâyihası ve İktisat, Maliye ve Bütçe encümenleri mazbataları. Cilt 4, Devre 6, İçtima F.

Umumi Murakabe Heyeti (1940a). Sümerbank 1938 senesi bilanço kar ve zarar hesapları tetkik ve tahlil raporu. Ankara: TBMM Matbaası.

Umumi Murakabe Heyeti. (1941a). Türkiye Şeker Fabrikaları Anonim Şirketi 1940 Yilı Raporu. Ankara: Ulusal Matbaa.

Umumi Murakabe Heyeti. (1941b). Sümerbank 1940 Yılı Raporu. İstanbul: Başarı Matbaasi.

Umumi Murakabe Heyeti. (1943). Türkiye Şeker Fabrikaları Anonim Şirketi 1942 Yilı Raporu. Ankara: İdeal Matbaa.

Veblen, T. (1919a). The place of science in modern civilisation and other essays. New York: B. W. Huebsch.

Veblen, T. (1919b). The vested interests and the state of the industrial arts. New York: B. W. Huebsch.

Veblen, T. (1923). Absentee Ownership and business enterprise in recent times the case of America London: George Allen \& Unwin, Ltd.

Veblen, T. (1932). The theory of business enterprise. New York: C. Scribner's Sons.

Veblen, T. (2011). Mühendisler ve fiyat sistemi.(Çev. B. Özçorlu).Ankara:EMO Yayınları.

Veldet, T. (1958). 30. Yılında Türkiye şeker sanayi (1926-1956). Ankara: Türkiye Şeker Fabrikalanı AŞ. Yayın No: 48.

Yerasimos, S. (1989). Azgelişmişlik sürecinde Türkiye, Cilt 3. (Çev. B. Kuzucu). İstanbul: Belge Yayınları.

Ziraat Bankası. (1940). Türkiye Cumhuriyeti Ziraat Bankasımın 1938 yılı bilanço kar ve zarar hesapları hakkında rapor. Ankara: TBMM Matbaası.

\section{Kaynakça Bilgisi / Citation Information}

Çetiner, Ö. (2020). Rafine edilmiş güç: Bir mücadele alanı olarak erken cumhuriyet döneminde şeker şirketleri. OPUS-Uluslararası Toplum Araştırmaları Dergisi, 15(10. Y11 Özel Sayıs1), 5496-5541. DOI: 10.26466/opus.744886 